
The United States Department of Agriculture and United States Department of Energy both place high importance on developing resources and conversion technologies for producing fuels, chemicals and power from biomass. The two departments are working together on several aspects of biomass energy. This report is the second to be produced from a joint project on synergies between commercial starch to ethanol technology and cellulosic biomass to ethanol technology. The first report was Determining the Cost of Producing Ethanol from Corn Starch and Lignocellulosic Feedstocks (2000) http://www.nrel.gov/docs/fy01osti/28893.pdf. Both of these and future joint biomass reports will be posted at http://www.eere.energy.gov/biomass/publications.html.

\section{$\underline{\text { Acknowledgements }}$}

The authors would like to acknowledge the following people who contributed to this report:

Frank Taylor, co-author of the Phase I report that preceded this, and Kevin Hicks for his valuable insight and review of the report from the USDA/ARS/ERRC office in Wyndmoor, PA Andy Aden from NREL, for reviewing the report and adding valuable input.

The authors would also like to acknowledge the external reviewers of this report: Mark Yancey from BBI International and Hosein Shapouri from USDA 


\title{
Feasibility Study for Co-Locating and Integrating Ethanol Production Plants from Corn Starch and Lignocellulosic Feedstocks
}

\author{
A Joint Study Sponsored by: \\ U.S. Department of Agriculture and
}

U.S. Department of Energy

\author{
Robert Wallace, Kelly Ibsen \\ National Renewable Energy Laboratory \\ National Bioenergy Center
}

\author{
Andrew McAloon, Winnie Yee \\ U.S. Department of Agriculture \\ Eastern Regional Research Center \\ Agricultural Research Service
}

\author{
National Renewable Energy Laboratory \\ 1617 Cole Boulevard \\ Golden, Colorado 80401-3393 \\ Eastern Regional Research Center \\ Agricultural Research Service \\ 600 E. Mermaid Lane \\ Wyndmoor, PA 19038-8598 \\ NREL/TP-510-37092 \\ USDA-ARS 1935-41000-055-00D
}




\section{NOTICE}

This report was prepared as an account of work sponsored by an agency of the United States government. Neither the United States government nor any agency thereof, nor any of their employees, makes any warranty, express or implied, or assumes any legal liability or responsibility for the accuracy, completeness, or usefulness of any information, apparatus, product, or process disclosed, or represents that its use would not infringe privately owned rights. Reference herein to any specific commercial product, process, or service by trade name, trademark, manufacturer, or otherwise does not necessarily constitute or imply its endorsement, recommendation, or favoring by the United States government or any agency thereof. The views and opinions of authors expressed herein do not necessarily state or reflect those of the United States government or any agency thereof.

Available electronically at http://www.osti.gov/bridge

Available for a processing fee to U.S. Department of Energy and its contractors, in paper, from:

U.S. Department of Energy

Office of Scientific and Technical Information

P.O. Box 62

Oak Ridge, TN 37831-0062

phone: 865.576 .8401

fax: 865.576 .5728

email: mailto:reports@adonis.osti.gov

Available for sale to the public, in paper, from:

U.S. Department of Commerce

National Technical Information Service

5285 Port Royal Road

Springfield, VA 22161

phone: 800.553 .6847

fax: 703.605.6900

email: orders@ntis.fedworld.gov

online ordering: http://www.ntis.gov/ordering.htm 


\section{Executive Summary}

In 1999, a joint study between USDA/ARS/ERRC and NREL was started to investigate synergies between commercial starch to ethanol technology and cellulosic biomass to ethanol technology, still in development. The study was broken into two phases:

- Phase I: In 2000, a joint report was published: Determining the Cost of Producing Ethanol from Corn Starch and Lignocellulosic Feedstocks http://www.afdc.doe.gov/pdfs/4898.pdf that investigated the capital and operating expenses related to corn to ethanol and cellulosic biomass to ethanol plants. The report describes the comparison of the processes, each producing 25 million gallons per year of fuel ethanol.

- In this report (Phase II), the investigation turned to identifying scenarios where capital equipment, operating expenses and co-products could be shared in order to find an overall savings compared to a "stand alone" cellulosic facility using corn stover feedstock. Integration between the two processes occurred in the following areas:

- Combined utilities

- Combined ethanol purification

- Combined product processing

- Combined fermentation

In each of the above scenarios, a case was investigated where the solids (DDGS and lignin residue) streams, when combined, were combusted in the corn stover plant's fluidized bed combustor. Sensitivities were run where the combined solids were sold as a co-product with a value proportional to the protein content as compared to DDGS.

Three cases (combined utilities, combined ethanol purification and combined C6 fermentation with the $\mathrm{C} 5$ stream being sold) showed an economic benefit to a stand-alone corn stover to ethanol plant under the study assumptions (Table E1). Both cases where the solids were kept separate and the DDGS was sold as a co-product and the lignin residue was combusted to provide steam and electricity for the combined process realized an economic advantage compared to a stand alone 50 million annual gallon stover plant. The following table lists the pertinent corn, stover, DDGS and methane costs used in the study.

Table E1. Feedstock, Co-product and Natural Gas Costs

\begin{tabular}{|c|c|}
\hline Corn & $\$ 2.25 / \mathrm{bu}$ \\
\hline Stover & $\$ 40 / \mathrm{bdt}$ \\
\hline DDGS Selling Price & $\$ 80 /$ ton \\
\hline Natural Gas & $\$ 4 / \mathrm{MMBtu}$ \\
\hline
\end{tabular}


Figure E1 shows the annual ethanol production costs for all of the base case scenarios investigated. As stated above, three scenarios showed an economic advantage to a stand alone 50 million annual gallon stover plant.

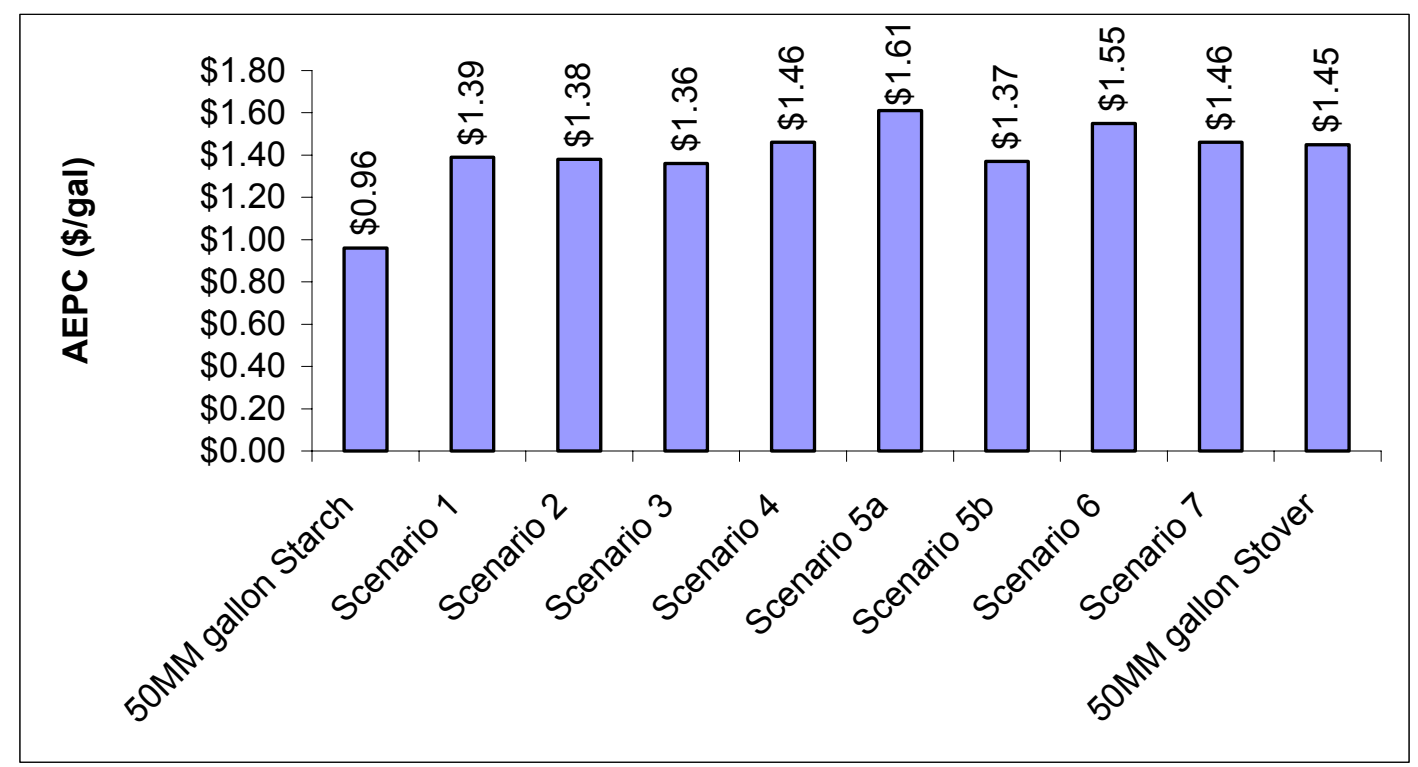

Figure E1. Annual Ethanol Production Cost Summary

This study highlighted the importance of DDGS or some other high value co-product for ethanol production from both corn and lignocellulosic feedstocks. It also demonstrated the importance of converting all the carbohydrates in stover to ethanol.

The analysis also suggests qualitative benefits. A facility built to process both corn and lignocellulosic feedstocks has flexibility to process one or both depending on the best value feed. Installing a Fluidized Bed Combustor creates flexibility in fuel options, from natural gas, biomass, and coal. The required radius of transportation decreases when stover is used in ethanol production. 


\section{Table of Contents}

Executive Summary iii

List of Figures $\quad$ vi

List of Tables vii

List of Acronyms viii

I Introduction 1

II Process Description 3

a. Corn Starch Feedstock-to-Ethanol Process Description 3

b. Lignocellulose Feedstock-to-Ethanol Process Description 5

c. Primary Process Differences 6

III Phase I Results 8

IV Changes between Phase I and Phase II to Base Models 9

a. Starch Model $\quad 10$

b. Lignocellulosic Model 10

V Phase II $\quad 12$

a. Objectives 12

b. Scenarios 12

c. Sensitivities 17

VI Phase II Results 19

a. Base Case Summary 19

b. Detailed Base Case Scenario Results 20

c. Sensitivity Results 24

VII Conclusions 28

VIII Ongoing Projects 29

Appendices

Appendix A MS Excel Summary Sheets for Base Case ASPEN Models 33

Appendix B MS Excel Summary Sheets for Sensitivity Cases where Solids Are Dried and Sold and Evaporation Takes Place ASPEN Models 47

Appendix C MS Excel Summary Sheets for Sensitivity Cases where Solids Are Dried and Sold and the Evaporators are Removed from the ASPEN Models 


\section{List of Figures}

Figure E1. Annual Ethanol Production Cost Summary iii

Figure 1. Corn starch-to-ethanol dry mill process flow 3

Figure 2 Lignocellulose-to-ethanol process flow 5

Figure 3. Comparative Production Costs for Starch and Lignocellulose Processes (1999\$)

Figure 4. Combined Utilities BFD 13

Figure 5. Combined Ethanol Purification BFD 14

Figure 6. Combined Product Processing with Combusted Solids BFD 15

Figure 7. Combined Fermentation Options 16

Figure 8. BFD of Sensitivity Model for Scenario 4 18

Figure 9. Base Case AEPC 19

Figure 10. Sensitivity Case Annual Ethanol Production Costs 24

Figure 11. DDGS Selling Price Sensitivity 27

Figure 12. nth Plant Feedstock and Enzyme Cost Sensitivity 28 


\section{List of Tables}

Table E1. Feedstock, Co-product and Natural Gas Costs iii

Table 1. Corn and Stover Compositions 2

Table 2. $\quad$ DDGS and Lignocellulosic Residue Composition and Production 8

Table 3. Summary of Capital and Operating Costs in Phase I Report 9

Table 4. Summary of Starting Capital and Operating Costs in Phase II 12

Table 5. Cost Breakdown of Stand Alone and Combined Scenario 1 Model 20

Table 6. $\quad$ Comparing Scenario 2 21

Table 7. Comparing Scenario 3 21

Table 8. Comparing Scenario $4 \quad 22$

Table 9. Comparing Scenarios 5a and 5b 22

Table 10. Comparing Scenario 6 23

Table 11. Comparing Scenario 7 24

Table 12. Solids Concentration entering Pneumapress without Evaporation 25

Table 13. Protein Content and Selling Price for DDGS and the Combined Solids 25

Table 14. Sensitivity Results of Selling Solids with Evaporators 26

Table 15. Sensitivity Results of Selling Solids with Evaporators Removed 26 


\section{List of Acronyms}

NGB

NREL

USDA

ERRC

ARS

DOE

NBC

C5

C6

CSTR

WWT

TCI

TO

$\mathrm{CH}_{4}$

$\mathrm{CO}_{2}$

BFD

GMO

MM\$

BTU

ORNL

INEEL

AEPC

NOC

DDRD

Bdt

FBC
Natural Gas Boiler

National Renewable Energy Laboratory

United States Department of Agriculture

Eastern Regional Research Center

Agricultural Research Center

Department of Energy

National Bioenergy Center

5 Carbon Sugars

6 Carbon Sugars

Continuously Stirred Tank Reactor

Waste Water Treatment

Total Capital Investment

Thermal Oxidizer

Methane

Carbon Dioxide

Block Flow Diagram

Genetically Modified Organism

Million Dollars

British thermal unit

Oak Ridge National Laboratory

Idaho National Energy and Environmental

Laboratory

Annual Ethanol Production Cost

Net Operating Costs

Director's Discretionary Research \&

Development

Bone dry ton

Fluidized Bed Combustor 


\section{I: Introduction}

The U.S. Department of Energy (DOE) is promoting the development of ethanol from lignocellulosic feedstocks as an alternative to conventional petroleum transportation fuels. Programs sponsored by DOE range from research to develop better cellulose hydrolysis enzymes and ethanol-fermenting organisms, to engineering studies of potential processes, to co-funding initial ethanol from lignocellulosic biomass demonstration and production facilities. This research is conducted by various national laboratories, including the National Renewable Energy Laboratory (NREL), Oak Ridge National Laboratory (ORNL) and Idaho National Engineering and Environmental Laboratory (INEEL), as well as by universities and private industry. Engineering and construction companies and operating companies are generally conducting the engineering work.

The U.S. Department of Agriculture (USDA) has an active program devoted to the corn ethanol industry. This program includes economic and policy studies by the Office of Energy Policy and New Uses (OEPNU) and the Economic Research Services (ERS), scientific research programs by the Agricultural Research Service (ARS) and the Cooperative State Research, Education and Extension Services (CSREES). Areas of scientific research address the establishment of new higher-value ethanol co-products, the development of microbes capable of converting various biomass materials into ethanol, improved processes for the enzymatic saccharification of corn fibers into sugars, and various methods of improving corn ethanol process efficiencies.

The maturing corn-to-ethanol industry has many similarities to the emerging lignocellulose-to-ethanol industry. It is certainly possible that some of the early practitioners of this new technology will be the current corn ethanol producers. ${ }^{\text {i,ii,iii }}$ In order to begin to explore synergies between the two industries, a joint project between two agencies responsible for aiding these technologies in the Federal government was established. This joint project of the USDA-ARS and DOE with NREL looked at the two processes on a similar process design and engineering basis and explored ways to combine them. The first report (Phase I) describes the comparison of the processes, each producing 25 million gallons per year of fuel ethanol. This report (Phase II) investigates combining the two processes at different points to examine possible advantages to collocation. Both studies attempted to compare the two processes as mature technologies, which requires assuming that the technology improvements needed to make the lignocellulosic process commercializable are achieved, and enough plants have been built to make the design well understood. Assumptions about yield are based on the successful NREL pilot scale demonstration of technologies that exist for the lignocellulose process. In order to compare the lignocellulose-to-ethanol process costs with the commercial corn-to-ethanol costs, it was assumed that the lignocellulose plant was an $\mathrm{N}^{\text {th }}$ generation plant, assuming no first-of-a-kind costs. This places the lignocellulose plant costs on a similar level with the current, established corn ethanol industry, whose costs are well known. 
Corn kernels have starch, which is an alpha-linked glucose polymer that can be easily broken down to glucose monomers and fermented to ethanol. The fiberportion of the kernels encases the starch. Corn used fro ethanol production typically contains about $15 \%$ moisture. An approximate composition of corn is shown in Table 1. In this analysis of the dry mill corn-to-ethanol process, a slightly different and simpler composition for corn (on a dry weight basis, 70\% starch, and for non-fermentables, 18\% suspended and 12\% dissolved) was used. A corn cost of $\$ 2.25$ per bushel and a yield of 101.6 gallons per ton or 2.84 gallons per bushel (119.5 gallons per ton on a dry basis) was used for the phase II analysis. This is less than the stoichiometric yield of ethanol from starch because the fermentation process necessarily yields yeast cells and byproducts in addition to carbon dioxide and ethanol. Yield is primarily dependent on the starch content, which may vary considerably.

Corn stover contains considerable quantities of cellulose, a beta-linked glucose polymer, which is more difficult to break down to glucose monomers than the alpha-linked polymer in starch. In addition, it contains hemicellulose, which is a more complex polymer of several sugars. The predominant sugars in hemicellulose are xylose and arabinose. These five-carbon sugars can also be fermented to ethanol with the proper microorganism. The maximum theoretical yield from corn stover with the composition listed in Table 1 is 107 gallons per dry ton (or 91 gallons per ton at 15\% moisture). For this analysis, a yield of 79.5 gallons of pure ethanol per dry ton was used, which equates to an average yield of $74.3 \%$ of the cellulose and hemicelluosic polymers. Entwined around the two sugar polymers is lignin, a polymer that does not contain sugars. Lignin, like the fiber in corn, has a by-product value. The fiber from corn is mixed with proteincontaining steepwater, dried and sold as Distiller's Dried Grains with Solubles (DDGS). Lignin, currently recognized for its fuel value, may have a better co-product value, as yet unrealized. Stover is typically $15 \%$ moisture, although it can vary depending on age, growing, harvesting and storage conditions, and variety. Feedstock collection studies performed by ORNL and INEEL along with industrial partners have shown a range of delivered feedstock to the plant gate from $\$ 30-\$ 53^{\text {iv }}$ per dry ton. For this study, $\$ 40 / \mathrm{bdt}$ was assumed.

Table 1. Corn and Stover Compositions

\begin{tabular}{|l|r|l|r|}
\hline \multicolumn{1}{|c|}{ Corn $^{v}$} & \% Dry Basis & \multicolumn{1}{|c|}{ Corn stover $^{\text {vi }}$} & \% Dry Basis \\
\hline \hline Starch & 72.0 & Cellulose & 37.4 \\
\hline Hemicellulose/Cellulose & 10.5 & Galactan/Mannan & 3.6 \\
\hline Protein & 9.5 & Xylan & 21.1 \\
\hline Oil & 4.5 & Arabinan & 2.9 \\
\hline Sugars & 2.0 & Lignin & 18.0 \\
\hline Ash & 1.5 & Ash & 5.2 \\
\hline Total & 100.0 & Acetate & 2.9 \\
\hline & & Extractives & 4.7 \\
\hline & & Protein & 4.2 \\
\hline & & Total & 100.0 \\
\hline \% Moisture & 15.0 & \% Moisture & 15.0 \\
\hline
\end{tabular}


On a nation-wide average, 1 acre yields about 130 bushels ( 3.65 tons at $15 \%$ moisture) of corn, and that for every ton of corn; approximately 1 dry ton of stover is left on the field. Removing the stover from the field is a complex issue due to factors such as weather soil composition and terrain (flat, hilly, etc.). In some areas of the country, the amount of stover that will be able to be removed will be greater than $30 \%$ and in some areas, it will less. A rough estimate of about $33 \%$ of the stover is currently thought to be available for collection. The remaining stover needs to be left on the field for erosion control. With an estimated 240 million dry tons of stover produced, the 80 million dry tons available for harvesting is equivalent to 6 billion gallons of ethanol. However, as corn production increases to meet demand, stover production will increase as well.

\section{II: Process Descriptions}

Each process has the same general flow, from feedstock handling through fermentation to product and co-product recovery. The process details are outlined below.

\section{a. Corn Starch Feedstock-to-Ethanol Process Description}

Figure 1 depicts the dry mill process.

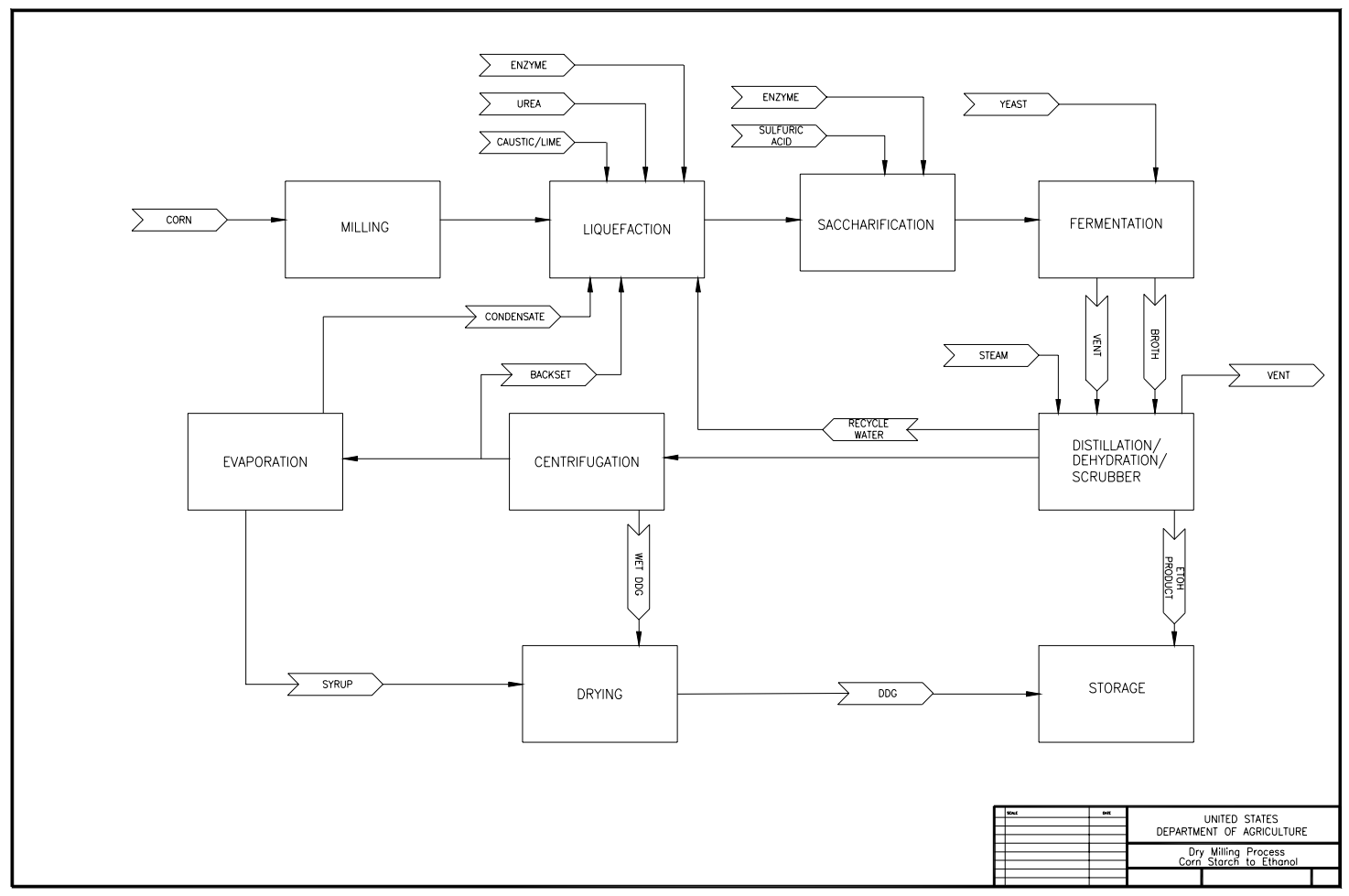

Figure 1. Corn starch-to-ethanol dry mill process flow

Corn is received and conveyed to two storage silos, having a combined capacity of 10 days. Stored corn is conveyed to grain-cleaning equipment where trash such as tramp metal and rocks $(0.3 \%)$ is removed, and then to hammer mills (two operating mills, plus 
one standby). The corn meal is metered to a continuous liquefaction tank, where it is mixed with hot evaporator condensate and purchased alpha-amylase enzyme. The condensate is heated with steam to maintain $88^{\circ} \mathrm{C}\left(190^{\circ} \mathrm{F}\right)$ in the tank. Used caustic from the clean-in-place system and lime are also added to provide optimum $\mathrm{pH}$ (6) and calcium for the alpha-amylase. Urea is added to provide nitrogen to the yeast fermentation. After liquefaction, backset (recycled thin stillage from the centrifuge) is added, amounting to $15 \%$ by volume of the final mash. Then the mash is heated to $110^{\circ} \mathrm{C}$ $\left(230^{\circ} \mathrm{F}\right)$, held for 20 minutes, and cooled to $60^{\circ} \mathrm{C}\left(140^{\circ} \mathrm{F}\right)$. Continuous saccharification takes place in a stirred tank where purchased glucoamylase is added with sulfuric acid for $\mathrm{pH}$ control (4.4). Residence time in the saccharification tank is 6 hours. The saccharified mash is cooled to $32^{\circ} \mathrm{C}\left(89^{\circ} \mathrm{F}\right)$ and fed to four continuous cascade fermentors where yeast is added. Total residence time in the fermentors is 46 hours. Temperature is maintained below $34^{\circ} \mathrm{C}\left(93^{\circ} \mathrm{F}\right)$ by recirculation through two external heat exchangers, and $\mathrm{pH}$ is maintained above 3.5. Recirculating the off-gas through a compressor mixes the airlift fermentors. The concentration of ethanol in the whole beer leaving the fermentors is $9 \%$ by weight ( $12 \%$ by volume).

In liquefaction, the alpha-amylase attacks the starch polymer randomly, producing maltose (di-glucose) and higher oligomers. In saccharification, the gluco-amylase attacks the non-reducing end of maltose and higher oligomers, splitting off glucose. In addition to the alpha 1-4 linkages, there are alpha 1-6 branch points. These are attacked by glucoamylase, or by pullulanase, which is specific for alpha 1-6 linkages. Pullulanase and other enzymes may be found as minor constituents of commercial enzymes, which are complex mixtures, rather than pure enzyme preparations. A recent development in drymill ethanol enzymes is alpha amylase containing some protease that makes some of the corn protein available for yeast nutrition.

The whole beer is heated, degassed, and fed to the beer column. Steam and cooling water for heating and cooling of the mash, whole beer, and whole stillage are conserved by the use of heat recovery exchangers. Fermentor off-gas and vapors from degassing the whole beer are sent to a water scrubber where ethanol vapor is removed and recycled. The scrubbed $\mathrm{CO}_{2}$ is released to the atmosphere. The whole stillage leaves the bottom of the beer column at less than $0.1 \%$ by weight ethanol. The overhead vapors pass to the bottom of the rectifier, where the concentration of ethanol is increased from $45 \%$ to $91 \%$ by weight. The bottoms from the rectifier are pumped to the top of the stripper. The bottoms from the stripper (less than $0.1 \%$ by weight ethanol) are recycled to the liquefaction tank along with evaporator condensate. The concentrated vapor from the rectifier is superheated and passes through one of two dehydrating molecular sieve beds; one is used while the other is regenerated. Vapors from the regenerated bed are condensed and recycled to the rectifier. The superheated vapor passing through the molecular sieve bed contains more than $99 \%$ by weight ethanol. The product is condensed, cooled, stored, denatured with gasoline ( $5 \%$ by volume), and shipped. Ethanol storage capacity is 12 days.

The whole stillage is partially evaporated in the first three stages of a six-effect vacuum evaporator. The partially evaporated whole stillage is separated in a decanter centrifuge 
(one operating plus one standby). The wet grains leave the centrifuge at $35 \%$ by weight total solids. The thin stillage from the centrifuge is partially recycled as backset, and the remainder is concentrated in the final three stages of the evaporator to syrup containing $55 \%$ by weight total solids. To conserve steam and cooling water, the condensation of overhead vapors from the rectifier to provide reflux for distillation is accomplished in the evaporator. The syrup and wet grains are mixed and dried in a gas-fired rotary dryer. The DDGS leaving the dryer contains $9 \%$ moisture by weight. With the edition of thermal oxidizers, the process is designed to be essentially zero-discharge. Makeup water is added only for the cooling tower and the $\mathrm{CO}_{2}$ scrubber, and no wastewater is produced.

\section{b. Lignocellulose Feedstock-to-Ethanol Process Description}

The process used in this analysis can be briefly described as using co-current dilute acid prehydrolysis of the lignocellulosic biomass with enzymatic saccharification of the remaining cellulose and co-fermentation of the resulting glucose and xylose to ethanol. In addition to these unit operations, the process involves feedstock handling and storage, product purification, wastewater treatment, lignin combustion, product storage, and other utilities. In all, the process is divided into eight areas (see Figure 2). Details of the process can be found in the NREL design report for the dilute acid prehydrolysis and enzymatic hydrolysis process. ${ }^{\text {vii }}$

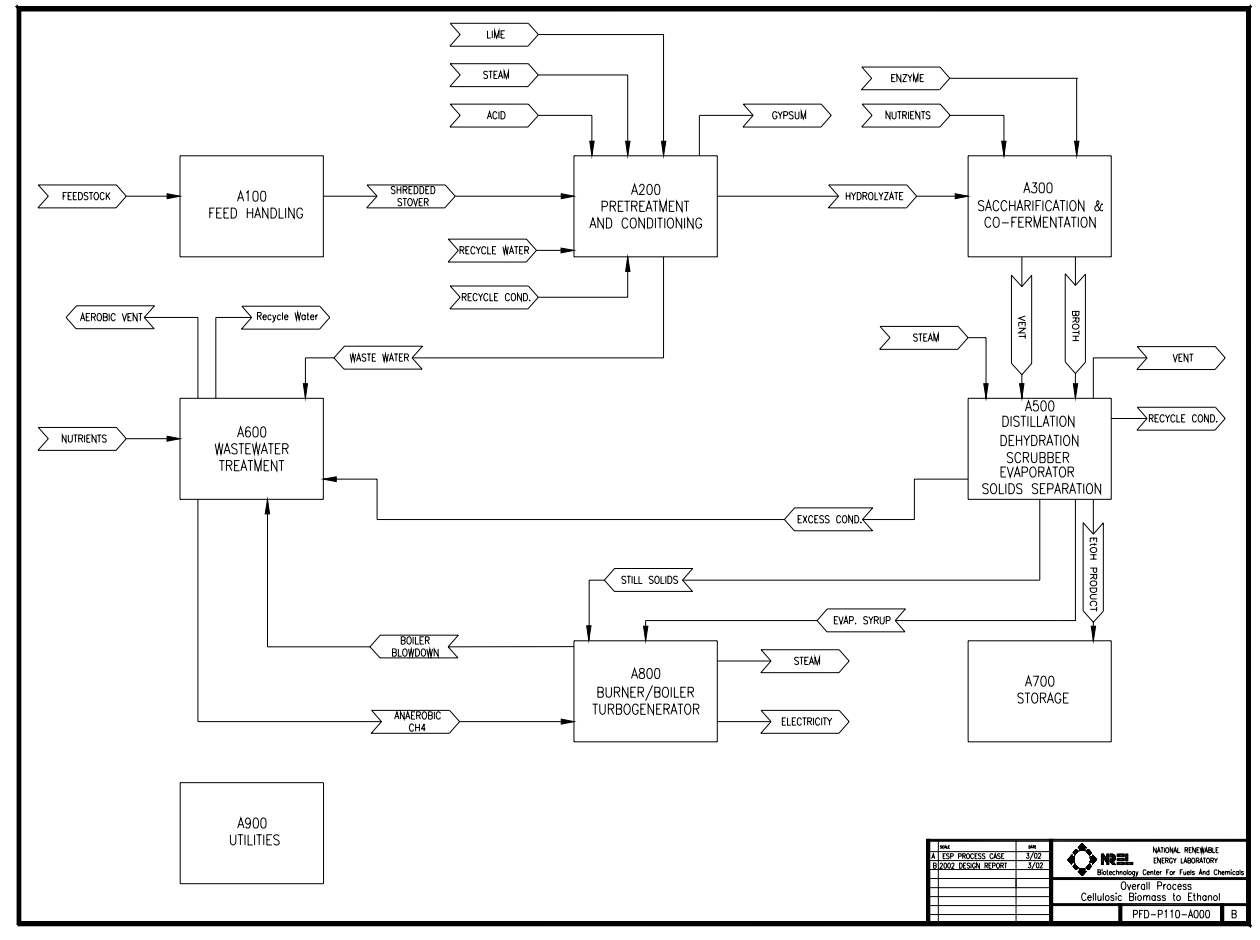

Figure 2. Lignocellulose-to-ethanol process flow

The feedstock, in this case corn stover, is delivered to the feed handling (A100) area for storage and size reduction. From there, the biomass is conveyed to pretreatment and 
conditioning (A200). In this area, the biomass is treated with dilute sulfuric acid (1.1\% $\mathrm{w} / \mathrm{v})$ at a high temperature and pressure $\left(190^{\circ} \mathrm{C}\right.$ and $13 \mathrm{~atm}$ respectively) for a very short time, liberating the hemicellulose sugars and other compounds. Overliming is required to remove compounds liberated in the pretreatment that will be toxic to the fermenting organism. Only the liquid portion of the hydrolysis stream is conditioned.

Saccharification and co-fermentation, although separate, are similar processes. Saccharification and co-fermentation (A300) of the hydrolyzate slurry are carried out in a series of continuous anaerobic fermentation trains. In saccharification, purchased cellulase enzyme is added to the first of a series of tanks where the enzyme hydrolyzes the cellulose into fermentable glucose. After almost complete saccharification, the cellulose/glucose stream is added to the hydrolyzate stream and sent to fermentation where most of the cellulose and xylose are converted to ethanol. The recombinantfermenting organism is grown in progressively larger batch anaerobic fermentations. This inoculum, and other nutrients, is added to the first fermentor. The resulting beer with $5-6 \%$ by weight ethanol is sent to product recovery.

Product recovery (A500) consists of a beer column to distill the ethanol from the majority of the water and residual solids. The vapor exiting the beer column is $40 \%$ by weight ethanol and feeds the rectification column. A mixture of nearly azeotropic $(92.5 \%)$ ethanol and water from the rectification column is purified to pure (99.5\%) ethanol using vapor-phase molecular sieves. The beer column bottoms are sent to the first effect of a three-effect evaporator. The rectification column reflux condenser provides heat for this first effect. After the first effect, solids are separated using a Pneumapress ${ }^{\circledR}$ and dried in a rotary dryer. The effluent is sent to the second and third evaporator effects. Most of the evaporator condensate is returned to the process as fairly clean condensate (a small portion, $10 \%$, is split off to waste water treatment to prevent build-up of low-boiling compounds) and the concentrated syrup contains $27 \%$ by weight total solids.

Biogas (containing $75 \%$ methane, and with a heating value of approximately 18,000 British thermal units, or Btu, per pound) is produced by anaerobic digestion of organic compounds in wastewater treatment. The treated water is considered suitable for recycling and is returned to the process, so there is no water discharge from the process.

The solids from distillation, the concentrated syrup from the evaporator, and biogas from anaerobic digestion are combusted in a fluidized bed combustor, or FBC, (A800) to produce steam for process heat. Soluble components in the wet boiler feed are combusted and some water vapor exits through the stack. The majority of the steam demand is for the pretreatment and distillation areas. Generally, the process produces excess steam that is converted to electricity for use in the plant; any excess electricity is sold to the local power grid.

\section{c. Primary Process Differences}

There are some major differences in the processing of corn starch versus stover. Stover requires more feed handling; it is currently envisioned that stover will be delivered in 
bales that must be washed, shredded, and then milled to achieve a particle size that can be conveyed to the process. However, research is being conducted at INEEL to investigate more economical ways to deliver corn stover to the plant gate. These include single pass collection, shredding and densification methods. Corn requires milling to a fine meal. The steps to reduce the carbohydrate polymers in stover to simple sugar monomers take considerably longer and are more energy intensive than for the starch in corn. The cellulose requires pretreatment approaching $180^{\circ}-200^{\circ} \mathrm{C}\left(356^{\circ}-392^{\circ} \mathrm{F}\right)$ with dilute acid to make the cellulose digestible by cellulase enzyme versus $80^{\circ}-90^{\circ} \mathrm{C}\left(176^{\circ}-194^{\circ} \mathrm{F}\right)$ for cooking the cornstarch. Less severe pretreatments methods for corn stover are currently being investigated, but to date, none have been promising enough to replace dilute acid pretreatment. After pretreatment, the cellulase enzyme and fermentation organism require about 3 days for conversion to ethanol, compared to 2 days for starch. The longer residence time increases the chance for contamination during SSCF and larger capital for the same throughput. The resultant beer is more dilute, and the mixing power requirements are higher due to higher solids content. Starch is converted using two main enzymes, alpha-amylase and gluco-amylase. These enzymes have improved over the years, and now convert essentially $100 \%$ of the starch to glucose, provided that the corn is finely ground and properly cooked.

The residual solids from each process have value as a by-product. The DDGS is high in protein and is sold for animal feed. The lignocellulosic residue has little or no food value by itself but has some energy value when used for boiler fuel. Table 2 shows the composition of the DDGS and lignocellulosic residue and their relative amounts for a 25 million annual gallon fuel ethanol plant. The lignocellulosic residue composition is determined in the process model. It should be noted that ethanol and possibly electricity are the only products of the lignocellulose plant considered here. Certainly, smallervolume niche products will emerge; products that can also be produced from the lignocellulose-derived sugars and that will have a significantly higher profit margin. This is also true for the starch process; higher value co-products such as zein proteins and corn fiber-based products are under study by the USDA. When these other products and their selling prices are figured into the analysis, the cost of fuel ethanol may decrease, just as the cost of gasoline is lowered by the sale of other petroleum products of crude oil. 
Table 2. DDGS and Lignocellulosic Residue Composition and Production

\begin{tabular}{|c|c|c|c|}
\hline DDGS & $\begin{array}{l}\% \text { As-is } \\
\text { Basis }\end{array}$ & Lignocellulosic Residue & $\begin{array}{l}\% \text { As-is } \\
\text { Basis }\end{array}$ \\
\hline Cellulose and Hemicellulose & 444.0 & Cellulose & 5.8 \\
\hline Protein & 27.0 & Hemicellulose & 3.4 \\
\hline Fat & 9.0 & Lignin & 14.7 \\
\hline Ash & 5.0 & Protein & 1.7 \\
\hline $\begin{array}{l}\text { Other (glycerol, other } \\
\text { organics) }\end{array}$ & 6.0 & Other Organics & 17.1 \\
\hline Moisture & 9.0 & Ash & 5.1 \\
\hline \multirow[t]{2}{*}{ Total } & 100.0 & Moisture & 52.2 \\
\hline & & Total & 100.0 \\
\hline $\begin{array}{l}\text { Tons per day at } 9 \% \\
\text { moisture }\end{array}$ & 243.6 & $\begin{array}{l}\text { Tons per day at } 58 \% \\
\text { moisture }\end{array}$ & 1126 \\
\hline $\begin{array}{l}\text { Pounds per gallon fuel } \\
\text { ethanol }\end{array}$ & 6.4 & $\begin{array}{l}\text { Pounds per gallon fuel } \\
\text { ethanol }\end{array}$ & 31.5 \\
\hline
\end{tabular}

\section{III: Phase I Results}

The figure below shows the production cost breakdown for each process producing 25 million gallons per year of ethanol. The largest cost contributor in the corn starch process is the feedstock; for the lignocellulosic process it is the depreciation of capital cost, which is represented by depreciation cost on an annual basis. The accompanying table below shows that both the capital and operating costs to produce ethanol from corn stover far exceed that of corn starch. 


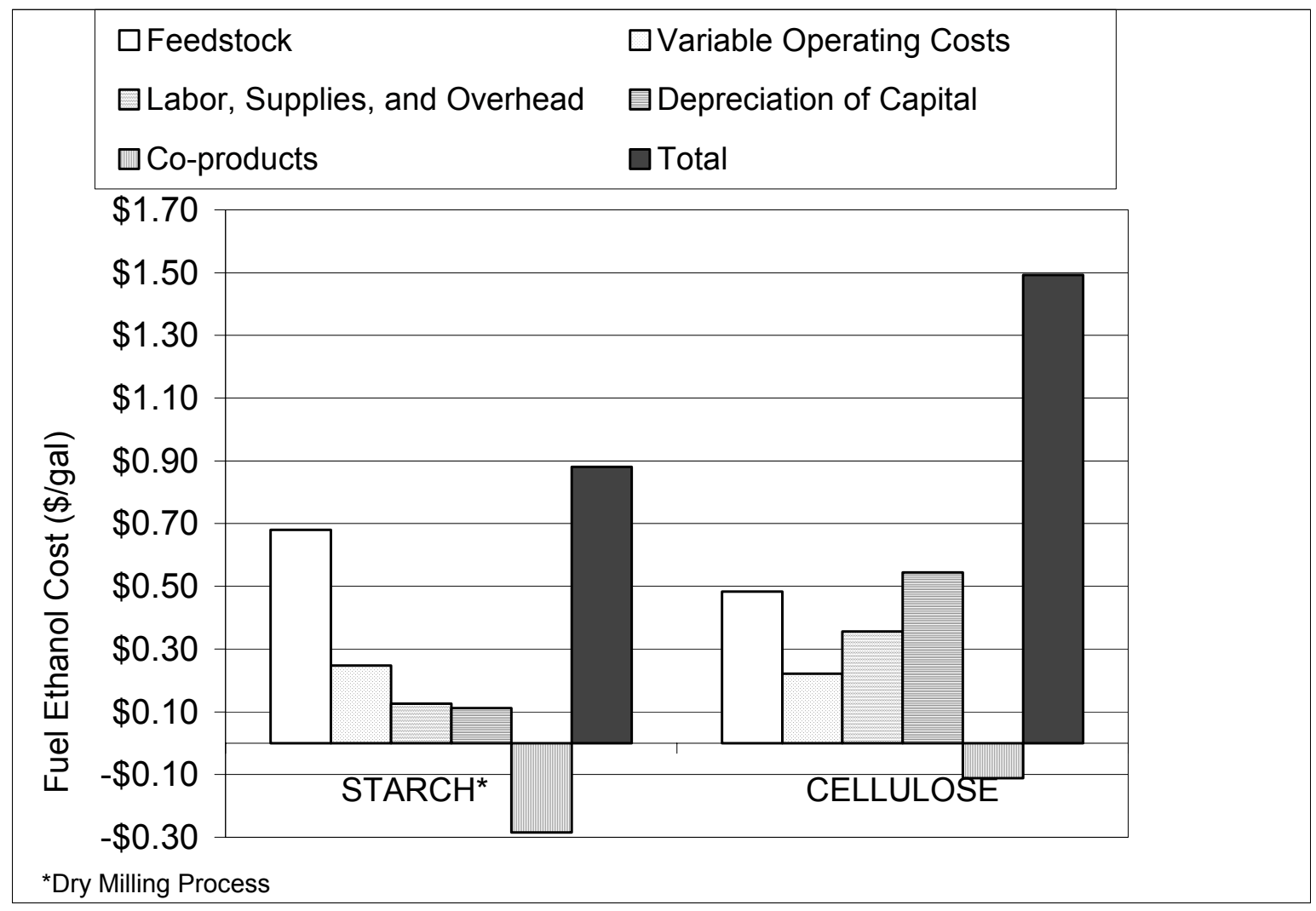

Figure 3. Comparative Production Costs for Starch and Lignocellulose Processes (1999\$)

Table 3. Summary of Capital and Operating Costs in Phase I Report

\begin{tabular}{|c|c|c|c|}
\hline Corn & & Corn Stover & \\
\hline All values in $1999 \$$ & & All values in $1999 \$$ & \\
\hline $\begin{array}{c}\text { Annual Ethanol Production } \\
\text { Cost }(\$ / \text { gal })\end{array}$ & $\$ 0.88$ & $\begin{array}{c}\text { Annual Ethanol Production } \\
\text { Cost }(\$ / \text { gal })\end{array}$ & $\$ 1.50$ \\
\hline Fuel Ethanol Yield (Gal/bu) & 2.85 & Fuel Ethanol Yield (Gal/bdt) & 72.0 \\
\hline Feedstock Cost (\$/bu) & $\$ 1.94$ & Feedstock Cost (\$/bdt) & $\$ 35.00$ \\
\hline $\begin{array}{c}\text { Total Capital Investment } \\
\text { (MM\$) }\end{array}$ & 27.9 & $\begin{array}{c}\text { Total Capital Investment } \\
\text { (MM\$) }\end{array}$ & 136.1 \\
\hline $\begin{array}{l}\text { Total Annual Production } \\
\text { Cost (MM } \$ / y r)\end{array}$ & 22.0 & $\begin{array}{l}\text { Total Annual Production } \\
\text { Cost (MM\$/yr) }\end{array}$ & 37.3 \\
\hline
\end{tabular}

\section{IV: Changes Between Phase I and Phase II to Base Models}

Since the Phase I report was published in 2000, both the USDA/ERRC/ARS and NREL have updated their models. Updates were made to the models because of advancements in research, more accurate information obtained for feedstock, capital and operating costs, changes in environmental regulations and current dry mill data among other things. Both the USDA and NREL use ASPEN Plus ${ }^{\mathrm{TM}}$, a chemical engineering simulation 
software package to model the mass and energy balances for both of the ethanol processes, and Microsoft Excel ${ }^{\mathrm{TM}}$ for creating costing and economic analysis models. In order to make the comparison, both portions of the new models had to be aligned as they were in the first phase. This alignment ensures that the models use similar assumptions and rigor in both process and economic calculations.

\section{a. Starch Model Changes from Phase I}

1) Production capacity was normalized at 25 million and 50 million gallons per year of fuel ethanol. The original USDA model used in Phase I addressed a facility with a production capacity of 25 million gallons per year.

2) The costs of raw material and chemicals, where applicable, were put on the same basis for both facilities. Yeast, urea, and enzymes are examples of purchased raw materials unique to the starch process. These costs were updated to reflect more current pricing.

3) The components were increased and the non-starch composition of corn was changed as follows. The $12 \%$ non-fermentable dissolved solids (NFDS) was broken down to $8 \%$ NFDS and $4 \%$ soluble protein. The $18 \%$ non-fermentable suspended solids was broken down to $4 \%$ oil, 5.8\% insoluble protein, 3\% C6 fiber (cellulose) and 5.2\% C5 fiber (hemi-cellulose).

4) A thermal oxidizer was added to the design to comply with current EPA regulations on DDGS dryer emissions.

5) Prices for corn, DDGS and natural gas were changed to 2002 values.

6) The Aspen properties method was changed from Wilson to NRTL.

7) The number of theoretical stages in the rectifier column was increased from 9 to 12 , and the number of theoretical stages in the stripper column was decreased from 9 to 6 .

8) The pressure specification for the gas side of the molecular sieves heat recovery heat exchanger (ED05) was decreased from 18.75 to 14.7 psi to prevent partial condensation of ethanol vapors.

9) Equipment cost changes were adjusted to $2002 \$$.

\section{b. Lignocellulose Model Changes from Phase I}

1) Starting with the model discussed in the 2002 design report vii, a simplified version was created as in the Phase I work. Production capacity was normalized at 25 million and 50 million gallons per year of fuel ethanol. The NREL model used in Phase I addressed a facility with a production capacity of 25 million gallons per year. 
2) Area 400, which was used for enzyme production in the Phase I design, has been removed. Enzyme will instead be produced locally and purchased through licensing agreements with enzyme suppliers. Cost estimates have been developed through the Biomass Program's current collaborations with enzyme manufacturers to develop commercially available enzyme preparations for lignocellulosic biomass. The 2002 design report uses a target value of $\$ 0.10$ per gallon; this study uses $\$ 0.30$ per gallon. This is on a stover basis; in other words, $\$ 0.30$ per gallon of corn stover derived ethanol.

3) The solid-liquid separation equipment in the pretreatment area was changed to a Pneumapress pressure filter, which provides automated batch filtration using compressed air and allows washing of the solids to increase sugar recovery.

4) Indices for chemicals, labor and equipment costs were updated.

5) Costs are in $\$ 2002$ in this report, updated from $2000 \$$ in the design report and compared to $1999 \$$ in phase I. Electricity and other common materials costs were normalized between the starch and stover models.

6) The feedstock is corn stover, compared to yellow poplar in the phase I work. This reflects a shift in the Biomass Program's focus to agricultural residues. Changes from this shift include the feedstock cost, composition, handling equipment (Area 100 ), and various process parameters and yields. Ion exchange was removed from the conditioning area since there is less acetate in stover than wood, and less acetic acid, an inhibitor to fermentation, is produced. A feedstock cost of $\$ 40$ per dry ton of corn stover is used in this study; the 2002 design report uses a target value of $\$ 30$ for a mature agricultural residue delivery infrastructure.

7) A worksheet called BOILECON was added to the Excel workbook to help track the boiler/burner/turbogenerator system in the simplified model.

The costs for 25 million gallon facilities using corn and stover are shown in Table 4. These are the starting cases for this phase II study. Using the NREL 2002 design report costs for feedstock and cellulase result in an ethanol production cost from corn stover of $\$ 1.36$ per gallon. 
Table 4. Summary of Starting Capital and Operating Costs in Phase II

\begin{tabular}{|c|c|c|c|}
\hline Corn & & Corn Stover & \\
\hline All values in $2002 \$$ & & All values in $2002 \$$ & \\
\hline $\begin{array}{c}\text { Annual Ethanol Production } \\
\text { Cost }(\$ / \mathrm{gal})\end{array}$ & $\$ 1.02$ & $\begin{array}{c}\text { Annual Ethanol Production } \\
\text { Cost }(\$ / \text { gal })\end{array}$ & $\$ 1.69$ \\
\hline Fuel Ethanol Yield (Gal/bu) & 2.84 & Fuel Ethanol Yield (Gal/bdt) & 79.2 \\
\hline Feedstock Cost (\$/bu) & $\$ 2.25$ & Feedstock Cost (\$/bdt) & $\$ 40.00$ \\
\hline $\begin{array}{c}\text { Total Capital Investment } \\
(\mathrm{MM} \$)\end{array}$ & $\$ 31.7$ & $\begin{array}{c}\text { Total Capital Investment } \\
(\mathrm{MM} \$)\end{array}$ & $\$ 120.7$ \\
\hline $\begin{array}{c}\text { Total Annual Production } \\
\text { Cost (MM\$/yr) }\end{array}$ & $\$ 25.6$ & $\begin{array}{c}\text { Total Annual Production } \\
\text { Cost }(\mathrm{MM} \$ / \mathrm{yr}) \\
\end{array}$ & $\$ 42.1$ \\
\hline
\end{tabular}

\section{V: Phase II}

\section{a. Objectives}

In Phase II, the investigation turned to identifying scenarios where capital equipment, operating expenses and co-products could be shared in a corn starch/stover 50MM gallon facility to find an overall savings compared to a separate "stand alone"50MM gallon stover facility. Areas for the investigation were combining utilities, ethanol purification, ethanol distillation and fermentation. The scenarios are progressive; process combinations made in earlier scenarios are included in successive scenarios. For comparison, a 50 million annual gallon starch ethanol plant is included as well as the 50 million gallon stover plant.

\section{b. Scenarios}

\section{Scenario 1: Two stand-alone 25MM gallon plants}

Scenario 1 represents corn starch and stover plants standing side by side, but with no integration. The plants share nothing but the same location. Figures 1 and 2 above show the basic schematic of a starch ethanol and stover plant respectively. From this starting scenario, a combined plant spreadsheet was made with both plants' costs and power requirements included.

\section{Scenario 2: Combined Utilities}

In this scenario, the natural gas boiler used in the corn to ethanol plant was discarded and its steam and electricity needs were supplied with the FBC and turbogenerator (Figure 4). In order to meet the demands of the corn to ethanol plant, extra boiler fuel is required. This is true for all the scenarios in this study where a FBC is used, aside from the standalone stover plant. The extra boiler fuel supplied is corn stover, and is fed directly into the FBC. To supply the steam and electricity for the corn to ethanol plant, $3,750 \mathrm{~kg} / \mathrm{hr}$ (100 ton/day) of corn stover was fed to the FBC. A single steam stream was added to the 
NREL ASPEN+ model to represent the steam demand of the starch plant. Electricity requirements of the starch plant were subtracted from the excess electricity produced by the stover plant.

Starch Plant

Stover Plant

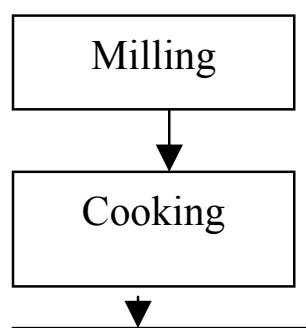

Liquefaction

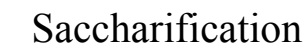

\section{Saccharification}
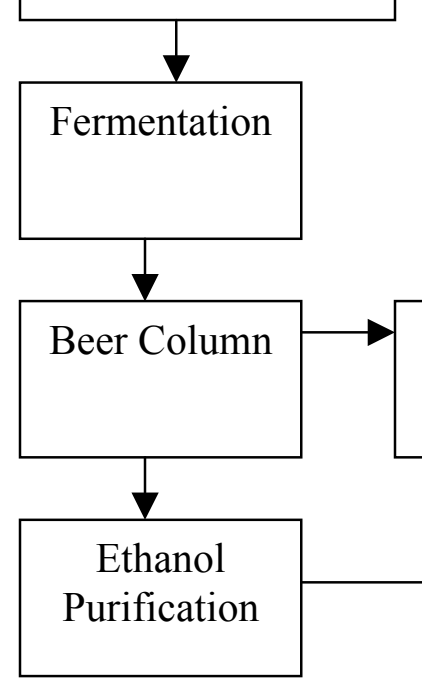

Figure 4. Combined Utilities BFD

\section{Scenario 3: Combined Ethanol Purification}

In this scenario, the vapor leaving the top of the starch-side beer column is added to the stover plant's rectifier as shown in Figure 5. The DDGS stream comes from the bottom of the starch beer column and is not affected by the combined purification. Therefore, DDGS is still sold as a co-product and the lignin stream is burned to provide steam and electricity. The model was constructed with the utilities being shared. 
Starch Plant

Stover Plant

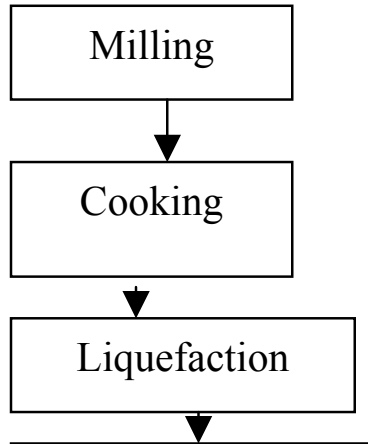

Milling

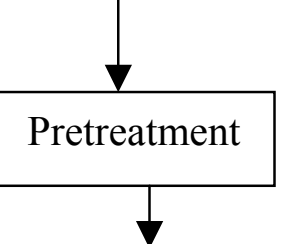

Saccharification

\section{Saccharification}

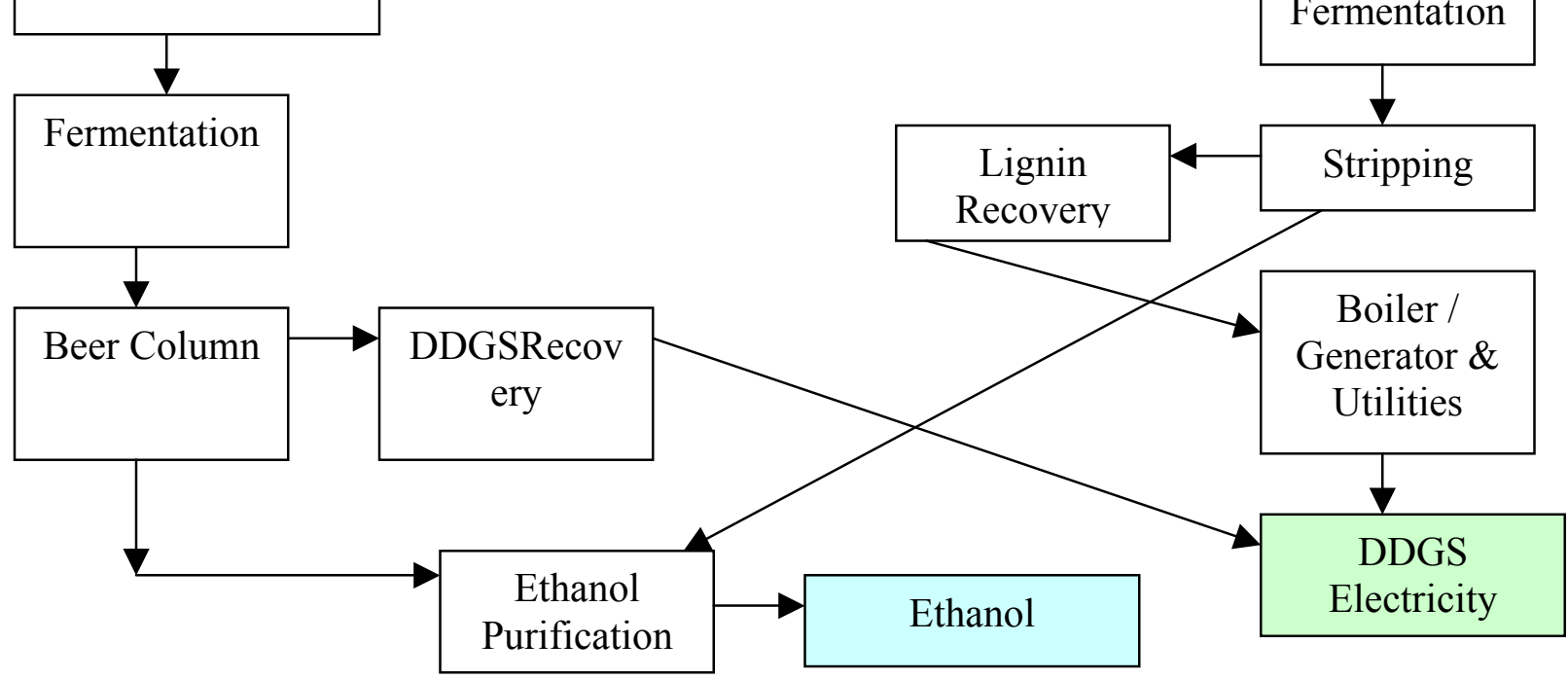

Figure 5. Combined Ethanol Purification BFD

\section{Scenario 4: Combined Product Processing}

In combined product processing, the starch and stover plants share distillation and purification steps, as shown in Figure 6. Combining equipment in distillation and downstream realizes savings due to factors in scale. Due to the size of the flow through distillation, there are small losses in the amount of ethanol produced. Beginning with this scenario, the residual solids from the starch (wet distillers grains) and stover (cellulose and lignin) processes become combined. To understand the effects of this, two options were considered: 1) burning the combined solids - the base case, or 2) selling the combined solids based on their protein concentration. The base case is shown in the following scenarios; the second option is discussed in the sensitivities section of the report. The latter case was chosen because at present, it is not known what other value the combined stream may have. However, it is very unlikely that a feeder would use this product because of both its low protein content and the poor digestibility of the cellulose/lignin content of the stream. 
Starch Plant

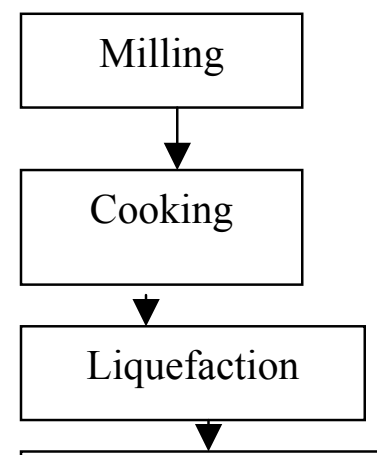

Stover Plant

Milling

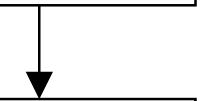

Pretreatment
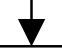

tion

Saccharification

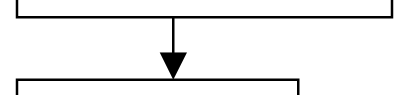

Fermentation

Ethanol

Purification

Ethanol

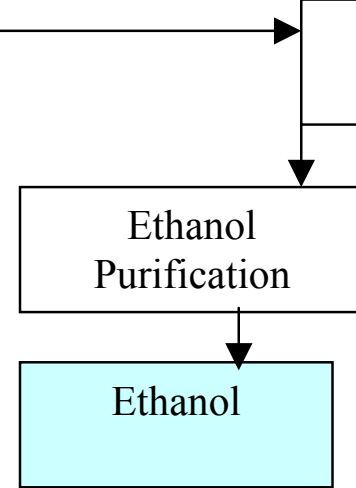

Beer Column

Figure 6. Combined Product Processing with Combusted Solids BFD

The next three scenarios involve combining the starch and stover fermentation steps and varying the fate of the hemicellulose sugars. Figure 7 provides a schematic of the three fermentation scenarios with the hemicellulose sugar routes labeled. 
Starch Plant

Stover Plant

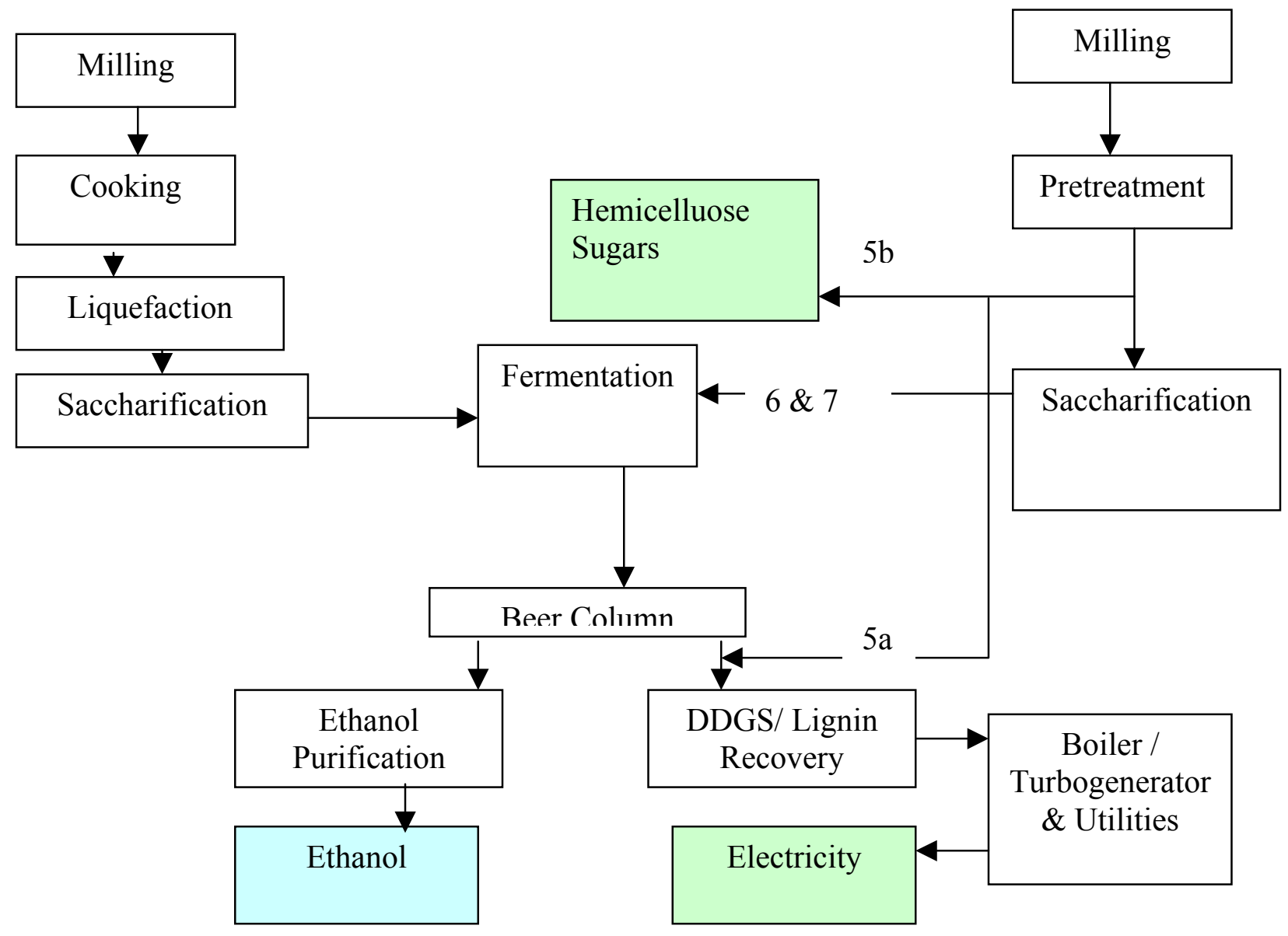

Figure 7. Combined Fermentation Options

\section{Scenario 5: Combined Starch and Cellulose Fermentation}

In this scenario, the hydrolyzate liquor (containing xylose and other minor hemicellulosic sugars) is not recombined with the solids from the Pneumapress. Two variations were investigated in this scenario:

a. Diverting the liquor around fermentation which results in the hemicellulose sugars being in the solids, or

b. Selling the liquor without any modification as a hemicellulose sugar co-product

In diverting the liquor, sugars that will not be fermented but could be a feed source for contaminant organisms are routed around the fermentation. The hemicellulose sugar stream has potential value but probably needs to be concentrated and purified. In this study, we assume that the stream is sold over the fence as is and that the buyer will process the stream (for example by evaporation and liquid chromatography) for their own purposes. 
It was decided not to separately ferment the liquor because it would raise the capital costs without adding any value that is not already present in a combined fermentation scenario (scenario 6). Figure 7 provides a schematic of this scenario with the 2 options for the liquor fate labeled $5 \mathrm{a}$ and $5 \mathrm{~b}$.

\section{Scenario 6: Combined Starch and Six Carbon Sugar Fermentation}

In this scenario, the hydrolyzate liquor is recombined prior to fermentation, allowing the six carbon sugars that are in the stream to be fermented by a standard ethanologen like yeast. In this case, there is $10 \%$ less ethanol produced (45MMgal) because the xylose and arabinose are not fermented.

\section{Scenario 7: Combined Starch and Stover Fermentation}

In this scenario, the fermentation organism is assumed to ferment all five and six carbon sugars. There are several research groups currently developing both bacteria and yeast strains capable of multi-sugar conversion to ethanol.

\section{c. Sensitivities}

The base case for each scenario with combined solids combusts the solids stream in a FBC to produce steam and electricity for the process. This option eliminates a solid coproduct but electricity is still being sold as a coproduct. For each scenario where there were combined solids from the corn starch and stover plants the option of selling the solids based on their protein content was investigated, and two process designs were considered - with and without evaporation. In the base cases, the evaporators concentrate the solids streams prior to combustion. In the sensitivity cases, they concentrate prior to drying. The bottoms stream of the beer column is sent to the first stage of a three-stage evaporator where a portion of the liquid is evaporated. The exiting stream is then sent through a solid liquid separation step using a Pneumapress ${ }^{\circledR}$ air forced separation. The solids are then sent to a dryer to be further dried while the liquid stream is sent back to the last two stages of the evaporators to be further concentrated. The final concentrated liquor is mixed with the solids stream prior to drying. The FBC is replaced with a natural gas boiler.

The coproduct value was determined by the protein content as a percentage of the protein content in the DDGS stream in the scenarios where the solids were not combined. The FBC was replaced with a natural gas boiler. The capital cost reduction is offset by the cost of purchasing natural gas. 
Starch Plant

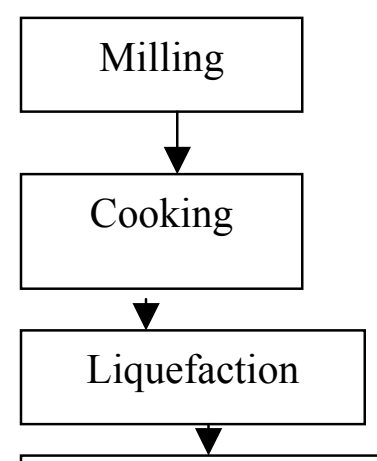

Stover Plant

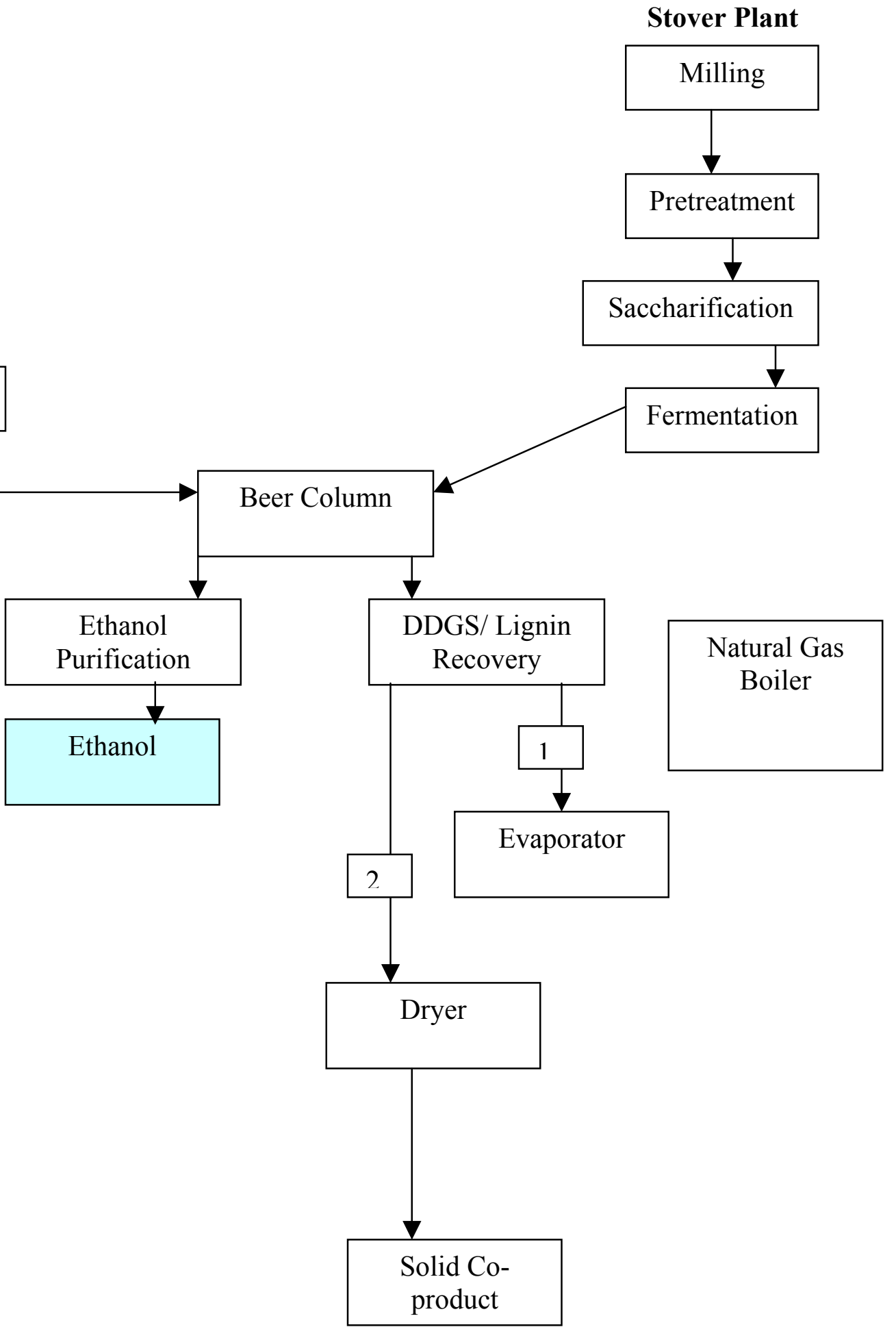

Figure 8. BFD of Sensitivity Model for Scenario 4 
1) The combined solids stream was sent through an evaporation step (first effect) a solid liquid separation step, and a drying step and sold as a coproduct. In this design, the liquid from the separation is concentrated in the evaporator's second and third effect and added to the solids entering the dryer and ends up in the coproduct.

2) The evaporation step was eliminated and the combined solids stream was sent directly to a solid liquid separation step and a drying step and sold as a coproduct. In this design, the liquid from the separation is sent to wastewater treatment where it is converted to methane for the natural gas boiler. By eliminating the evaporation step, there is a considerable savings in capital costs and also some savings in steam usage.

\section{VI: Phase II Results}

\section{a. Base Case Summary}

Figure 9 shows the base case annual ethanol production costs of all the scenarios compared to a stand alone corn starch and stover plant. All plants are 50 million gallons except those with reduced hemicellulose fermentation (scenarios $5 \mathrm{a}, 5 \mathrm{~b}$ and 6 ).

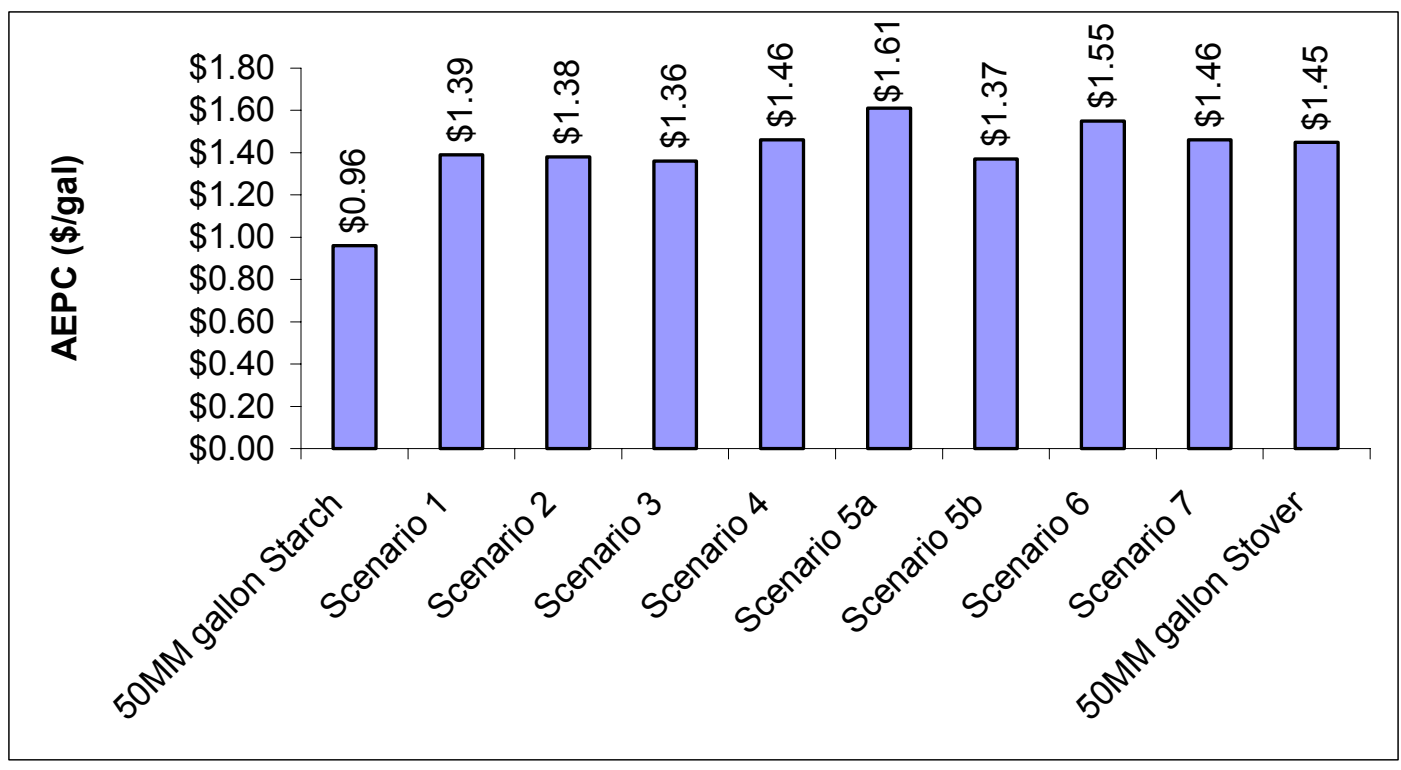

Figure 9. Base Case Annual Ethanol Production Costs

Scenarios 4-7 suffer from the loss of the DDGS co-product value. Scenarios 5a and 6 suffer from reduced ethanol production. Scenario 4 vs. 7 show there is no benefit to combining fermentations, probably because the tanks scale linearly. The only combined scenarios that have better economics than a stand alone stover facility are scenarios 2, 3 and $5 \mathrm{~b}$; combined utilities, ethanol purification and combined $\mathrm{C} 6$ fermentation with the 
C5 stream being sold separately, due to the economies of scale available in distillation equipment and the added value of the C5 stream in the last case.

\section{b. Detailed Base Case Scenario Results}

\section{Scenario 1: Two stand-alone 25MM gallon plants}

Scenario 1 is in fact nothing more than separate facilities. However, on paper two 25 million annual gallon facilities are combined so that a base cost could be used in comparison for the other scenarios. Scenario 1 has better economics than a stand alone 50 million gallon stover facility. This is due to the smaller capital investment of the starch to ethanol plant.

A 25 million annual gallon stover plant has an AEPC of $\$ 1.69 /$ gal. Because of the large capital investment for a stover plant, economies of scale are a more prevalent issue in the stover plant than the corn starch plant. The savings in AEPC for a corn starch plant in scaling up from 25 to 50 million gallons is $6 \phi /$ gallon, where in a stover plant, the saving is $31 \not /$ gallon. Table 4 below shows the breakout of costs for both 25 and 50 million gallons per year starch and stover facilities. Annual ethanol production costs (AEPC) include equipment costs, depreciation and net operating costs. Net operating costs include operating costs (feed, materials, labor) minus coproduct credits. Co-product credits can come from DDGS and/or electricity. Capital cost is reduced when half the plant is corn at the lower \$/annual gallon capital cost.

Table 5. Cost Breakdown of Stand Alone and Combined Scenario 1 Model

\begin{tabular}{|l|c|c|c|c|c|}
\hline & Corn Starch & Corn Starch & Corn Stover & Corn Stover & Combined \\
\hline $\begin{array}{l}\text { Annual Ethanol Output } \\
\text { (MMGal) }\end{array}$ & 25 & 50 & 25 & 50 & 50 \\
\hline $\begin{array}{l}\text { Annual Ethanol } \\
\text { Production Cost (\$/gal) }\end{array}$ & $\$ 1.02$ & $\$ 0.96$ & $\$ 1.76$ & $\$ 1.45$ & $\$ 1.39$ \\
\hline $\begin{array}{l}\text { Total Annual Production } \\
\text { Costs (MM\$/yr) }\end{array}$ & 25.6 & 47.8 & 43.9 & 72.0 & 69.5 \\
\hline $\begin{array}{l}\text { Co-product Credit (\$/gal) } \\
\begin{array}{l}\text { Net Operating Cost } \\
(\$ / g a l)\end{array}\end{array}$ & 0.26 & 0.26 & 0.13 & 0.13 & 0.20 \\
\hline $\begin{array}{l}\text { Total Capital Investment } \\
(\mathrm{MM} \$)\end{array}$ & $\$ 0.90$ & $\$ 0.86$ & $\$ 1.28$ & $\$ 1.06$ & $\$ 1.09$ \\
\hline
\end{tabular}

\section{Scenario 2: Combined Utilities}

Combining the utilities sections of the two plants realizes a $1 \phi /$ gallon savings from scenario 1. The total capital cost of the combined plants actually increases, even with the natural gas boiler removed. The reason is that the FBC and turbogenerator are a more capital intensive, although more versatile, option for steam and power generation. In order to provide enough steam for the process, $3,750 \mathrm{~kg} / \mathrm{hr}$ of raw corn stover (100 
tons/day) must be fed to the FBC in addition to the solid residue, syrup and methane from the stover plant. The savings by combining utilities comes from the decrease in natural gas usage at $\$ 4 / \mathrm{Mbtu}$. If natural gas is $\$ 3 / \mathrm{Mbtu}$ or less, there is no savings. The table below breaks out the costs comparing scenarios 1 and 2 .

Table 6. Comparing Scenario 2

\begin{tabular}{|l|c|c|c|}
\hline & Scenario 1 & Scenario 2 & Corn Stover \\
\hline Annual Ethanol Output (MMGal) & 50 & 50 & 50 \\
\hline Annual Ethanol Production Cost (\$/gal) & $\$ 1.39$ & $\$ 1.38$ & $\$ 1.45$ \\
\hline Total Annual Production Costs (MM\$/yr) & 69.5 & 69.3 & 72.0 \\
\hline Co-product Credit (\$/gal) & 0.20 & 0.19 & 0.13 \\
\hline Net Operating Cost (\$/gal) & $\$ 1.09$ & $\$ 1.06$ & $\$ 1.06$ \\
\hline Total Capital Investment (MM\$) & 151.7 & 159.9 & 193.7 \\
\hline
\end{tabular}

The savings by combining utilities in the co-located configuration does favorably compare to a stover stand alone 50 million annual gallon facility.

\section{Scenario 3: Combined Ethanol Purification}

In this design, the rectifier column, vapor phase molecular sieves and storage of the final product are combined, realizing savings in total capital compared to previous scenarios due to economies of scale. Operating costs are also lower because of burning biomass instead of methane to produce the required steam for the plant (inclusion of scenario 1). To provide the steam required, $3,000 \mathrm{~kg} / \mathrm{hr}$ ( $80 \mathrm{ton} /$ day) of biomass must be added to the FBC. The result is a savings of $5 \phi$ /gallon compared to combined plants. This case compares favorably to a stand alone 50 million annual gallon stover plant. Table 7 summarizes scenario 3 and compares it to previous scenarios.

Table 7. Comparing Scenario 3

\begin{tabular}{|l|c|c|c|c|}
\hline & Combined & Scenario 2 & Corn Stover & Scenario 3 \\
\hline Annual Ethanol Output (MMGal) & 50 & 50 & 50 & 50 \\
\hline $\begin{array}{l}\text { Annual Ethanol Production Cost } \\
\text { \$/gal) }\end{array}$ & $\$ 1.39$ & $\$ 1.38$ & $\$ 1.45$ & $\$ 1.36$ \\
\hline $\begin{array}{l}\text { Total Annual Production Costs } \\
\text { (MM\$/yr) }\end{array}$ & 69.5 & 69.3 & 72.0 & 68.0 \\
\hline Co-product Credit (\$/gal) & 0.20 & 0.19 & 0.13 & 0.19 \\
\hline Net Operating Cost (\$/gal) & $\$ 1.09$ & 1.06 & $\$ 1.06$ & $\$ 1.05$ \\
\hline Total Capital Investment (MM\$) & 151.7 & 159.9 & 193.7 & 154.3 \\
\hline
\end{tabular}

\section{Scenario 4: Combined Product Processing}

This and all other scenarios from this point forward combine the solids streams and combust them in the FBC. By doing this, the DDGS co-product is lost. This is a major revenues stream for the plant and without it the plant cannot compete with any scenario in which there is a DDGS stream even though electricity is made and sold. 
In combined product processing, further savings are realized due to combining equipment. Combining distillation, a major capital investment in both plants into a single plant process decreases capital costs considerably. Table 8 compares the cost parameters for combined product processing with that of combined ethanol purification, the most promising co-location scenario thus far. It can be seen that there is an overall savings realized in capital investment, but the operating cost and the overall productions costs are significantly higher. This difference is directly related to the loss of the DDGS revenue.

Table 8. Comparing Scenario 4

\begin{tabular}{|l|c|c|}
\hline & Scenario 3 & Scenario 4 \\
\hline Annual Ethanol Output (MMGal) & 50 & 49.5 \\
\hline Annual Ethanol Production Cost (\$/gal) & $\$ 1.36$ & $\$ 1.46$ \\
\hline Total Annual Production Costs (MM\$/yr) & 68.0 & 72.2 \\
\hline Co-product Credit (\$/gal) & 0.19 & 0.07 \\
\hline Net Operating Cost (\$/gal) & $\$ 1.05$ & $\$ 1.16$ \\
\hline Total Capital Investment (MM\$) & 154.3 & 147.4 \\
\hline
\end{tabular}

\section{Scenario 5: Combined Starch and Cellulose Fermentation}

As previously mentioned, in this scenario the hydrolyzate liquor stream can either be sold as a "dirty" sugar stream or recombined and combusted. By not attempting to ferment the sugars in the stream, the overall annual ethanol production falls significantly. This fact combined with the loss of the DDGS stream make the 5a option (recombine after fermentation) less than promising. In the case where the liquor stream is sold (scenario $5 b$ ), enough additional revenue is realized to make up for the loss in ethanol production and the loss of the DDGS stream. Table 9 gives the results of scenarios $5 \mathrm{a}$ and $5 \mathrm{~b}$ and compares them with the best scenario (3).

Table 9. Comparing Scenarios 5a and $5 b$

\begin{tabular}{|l|c|c|c|}
\hline & Scenario 3 & Scenario 5a & Scenario 5b \\
\hline Annual Ethanol Output (MMGal) & 50 & 43.8 & 43.6 \\
\hline Annual Ethanol Production Cost $(\$ / g a l)$ & $\$ 1.36$ & $\$ 1.61$ & $\$ 1.37$ \\
\hline Total Annual Production Costs (MM\$/yr) & 68.0 & 70.3 & 59.9 \\
\hline Co-product Credit $(\$ /$ gal) & 0.19 & 0.15 & 0.38 \\
\hline Net Operating Cost $(\$ / g a l)$ & $\$ 1.05$ & $\$ 1.25$ & $\$ 1.07$ \\
\hline Total Capital Investment (MM\$) & 154.3 & 156.4 & 134.3 \\
\hline
\end{tabular}

In scenario $5 \mathrm{a}$, the production cost is much higher due to the loss of both the DDGS revenue and ethanol production. The capital costs are a little higher than scenario 3 because there is less ethanol being produced and therefore more mass exiting the bottoms of the beer column, increasing the size of the evaporators. This is somewhat offset by the lower cost of the fermentation area. 
In scenario $5 \mathrm{~b}$ where the liquor stream is sold, a price of $0.55 \phi / 1 \mathrm{~b}$ was assigned to the stream. This price was determined on the basis that a clean xylose-containing sugar stream could be sold for $6 \notin /$ dry-lb. This information was provided from a DDRD study done at NREL. Scenario $5 \mathrm{~b}$ has the lowest capital investment because all the unit operations downstream from pretreatment do not carry the liquor stream, thus reducing their size. The size of the stream that is separated is approximately $119,000 \mathrm{~kg} / \mathrm{hr}$. Separating this stream also reduces operating costs; especially steam in distillation. The added sales revenue $(\$ 0.31 / \mathrm{gal})$ for this stream also lowers the operating costs of the plant. The added revenue realized by selling the "dirty" sugar stream is not enough to compare favorably to scenario 3 , but it does compare favorably to a stand alone 50 million gallon stover plant.

\section{Scenario 6: Combined Starch and Six Carbon Sugar Fermentation}

The loss of the opportunity to ferment the five carbon sugars to ethanol figures negatively on the economics of this scenario, as does the loss of the DDGS revenue stream. Table 9 compares the scenario 6 and the best scenario economics.

Table 10. Comparing Scenario 6

\begin{tabular}{|l|c|c|}
\hline & Scenario 3 & Scenario 6 \\
\hline Annual Ethanol Output (MMGal) & 50 & 45 \\
\hline Annual Ethanol Production Cost (\$/gal) & $\$ 1.36$ & $\$ 1.55$ \\
\hline Total Annual Production Costs (MM\$/yr) & 68.0 & 69.5 \\
\hline Co-product Credit (\$/gal) & 0.19 & 0.11 \\
\hline Net Operating Cost (\$/gal) & $\$ 1.05$ & $\$ 1.22$ \\
\hline Total Capital Investment (MM\$) & 154.3 & 147.0 \\
\hline
\end{tabular}

\section{Scenario 7: Combined Starch and Stover Fermentation}

Scenario 7 is comparable to scenario 4 where all the sugars are fermented but in the same tanks. In fact, they have the same production costs. There are slight differences in overall capital and operating costs, but they are minor probably due to differences in costing used by NREL and USDA for the fermentors. Scenario 7 doesn't compare favorably because of the loss of the DDGS revenue stream. Table 10 compares the scenario 7 results to scenario 4 and scenario 3. 
Table 11. Comparing Scenario 7

\begin{tabular}{|l|c|c|c|}
\hline & Scenario 3 & Scenario 7 & Scenario 4 \\
\hline Annual Ethanol Output (MMGal) & 50 & 49 & 49.5 \\
\hline Annual Ethanol Production Cost $(\$ / g a l)$ & $\$ 1.36$ & $\$ 1.46$ & $\$ 1.46$ \\
\hline Total Annual Production Costs (MM\$/yr) & 68.0 & 71.8 & 72.2 \\
\hline Co-product Credit (\$/gal) & 0.19 & 0.10 & 0.07 \\
\hline Net Operating Cost $(\$ / g a l)$ & $\$ 1.05$ & $\$ 1.16$ & $\$ 1.16$ \\
\hline Total Capital Investment (MM\$) & 154.3 & 150.5 & 147.4 \\
\hline
\end{tabular}

\section{c. Sensitivity Results}

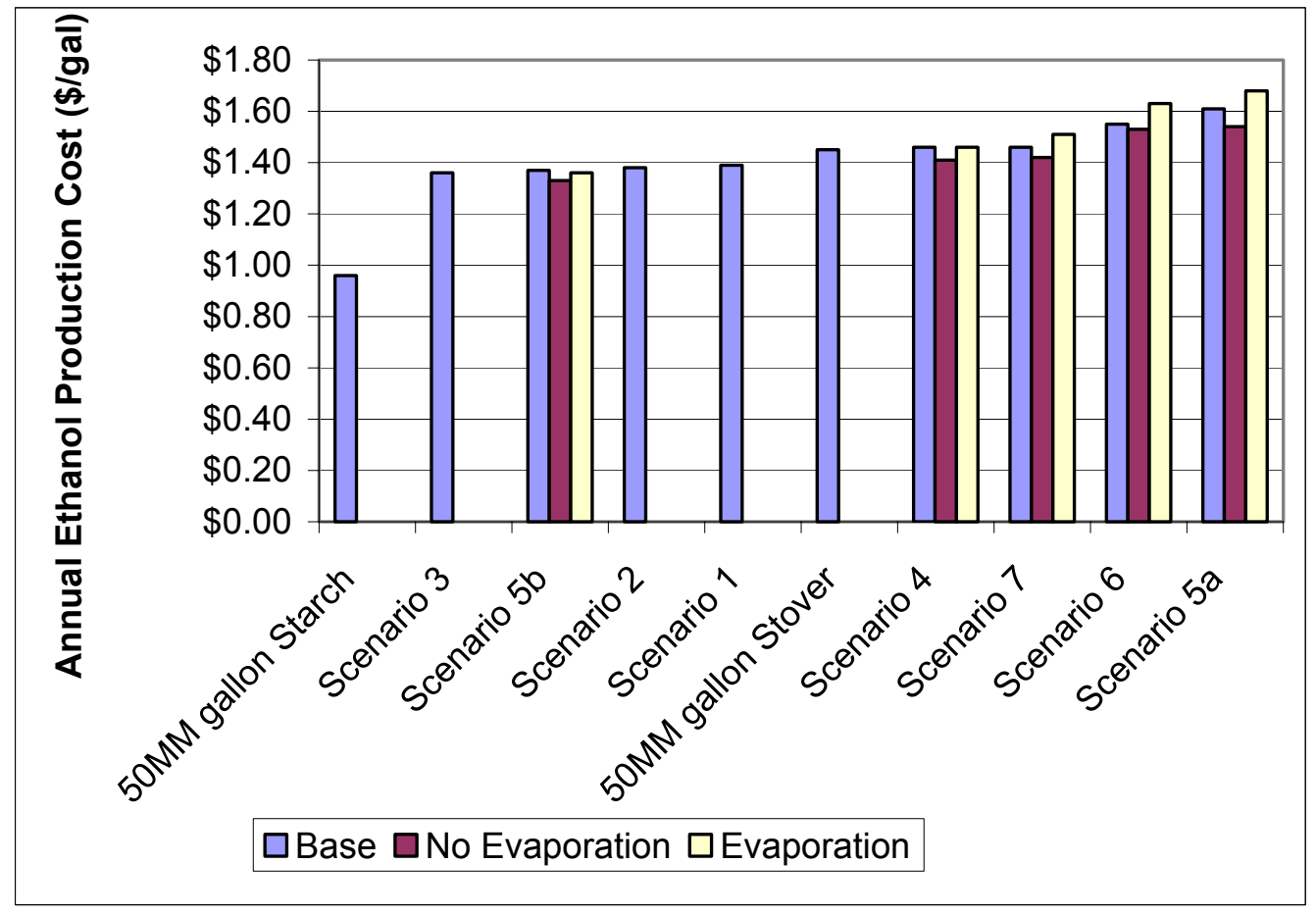

Figure 10. Sensitivity Case Annual Ethanol Production Costs

As discussed above in section V-c, two sets of sensitivities were run on all the cases where the solids streams were combined. Both sensitivities involved drying the combined solids stream to the same moisture content as DDGS, 9\%. One set of sensitivities left the evaporators in where the other removed them and sent the entire post distillation stream to waste water treatment. Capital is saved from the base cases by replacing the $\mathrm{FBC}$ with a natural gas boiler, but a dryer is added. Operating costs are increased by natural gas purchase.

By removing the evaporators, a large capital expense is removed, along with a minor operating cost from reduction in steam. When the evaporators are removed the effluent 
from the Pneumapress is sent to wastewater treatment. This increases the size and operating costs of the area, but also provides a larger biogas stream to the natural gas boiler to offset the purchase of exogenous natural gas. The table below lists the solids concentration of the streams entering the Pneumapress ${ }^{\circledR}$ without the evaporators.

Table 12. Solids Concentration entering Pneumapress ${ }^{\circledR}$ without Evaporation

\begin{tabular}{|c|c|}
\hline Scenario & Total Solids Concentration (\%) \\
\hline 4 & $13.94 \%$ \\
\hline $5 a$ & $14.45 \%$ \\
\hline $5 b$ & $14.17 \%$ \\
\hline 6 & $16.49 \%$ \\
\hline 7 & $14.18 \%$ \\
\hline
\end{tabular}

Another consideration to take into account when selling the solids stream is the protein content. Since at this time, there is no other known use for the solids, we are assuming that they will be used as an animal feed, and that the residual cellular protein from a GMO will not be an issue. DDGS is currently sold based on its protein content. By combining the solids, the overall amount of solids increases, but protein content decreases. For this report, the selling price of the combined solids is based on the selling price of DDGS and the relative protein content as compared to DDGS. Table 12 below lists the protein content and selling price of DDGS and the combined solids streams.

Table 13. Protein Content and Selling Price for DDGS and the Combined Solids

\begin{tabular}{|c|c|c|}
\hline USDA DDGS Protein Content & $28.30 \%$ & $\$ 80$ \\
\hline $\begin{array}{c}\text { Combined Solids With } \\
\text { Evaporators }\end{array}$ & Protein Content & $\begin{array}{c}\text { Selling Price } \\
(\$ / \text { ton })\end{array}$ \\
\hline 4 & $12.71 \%$ & $\$ 35.92$ \\
\hline $5 a$ & $11.50 \%$ & $\$ 32.50$ \\
\hline $5 b$ & $12.35 \%$ & $\$ 34.93$ \\
\hline 6 & $11.42 \%$ & $\$ 32.27$ \\
\hline 7 & $11.82 \%$ & $\$ 33.40$ \\
\hline $\begin{array}{c}\text { Combined Solids with } \\
\text { Evaporators Removed }\end{array}$ & Protein Content & $\begin{array}{c}\text { Selling Price } \\
(\$ / \text { ton })\end{array}$ \\
\hline 4 & $12.92 \%$ & $\$ 36.52$ \\
\hline $5 a$ & $11.67 \%$ & $\$ 32.98$ \\
\hline $5 b$ & $12.46 \%$ & $\$ 35.22$ \\
\hline 6 & $11.66 \%$ & $\$ 32.95$ \\
\hline 7 & $12.03 \%$ & $\$ 34.02$ \\
\hline
\end{tabular}

As table 13 illustrates, combining the solids greatly reduces the value as a feed when viewed strictly on a protein basis. The combination of low protein content and the high content of undigestible cellulose and lignin make the reality of the solids being of any value as a animal feed. It's possible that the solids have some other value to the animal 
that is yet undefined. The following two tables list the economic results of the sensitivities with and without evaporators respectively.

Table 14. Sensitivity Results of Selling Solids with Evaporators (soluble solids to co-product)

\begin{tabular}{|c|c|c|c|c|c|}
\hline Evaporators Used & $\begin{array}{c}\text { Annual Ethanol } \\
\text { Output (MMGal) }\end{array}$ & $\begin{array}{c}\text { Annual Ethanol } \\
\text { Production Cost } \\
(\$ / \text { gal) }\end{array}$ & $\begin{array}{c}\text { Net Operating } \\
\text { Cost }(\$ / \text { gal) }\end{array}$ & $\begin{array}{c}\text { Total Capital } \\
\text { Investment } \\
(\mathrm{MM} \$)\end{array}$ & $\begin{array}{c}\text { Operating Costs } \\
(\mathrm{MM} \$ \mathbf{y r})\end{array}$ \\
\hline Scenario 3 & 50 & $\$ 1.36$ & $\$ 1.05$ & 154.3 & 68.0 \\
\hline Stover Plant & 50 & $\$ 1.45$ & $\$ 1.06$ & 193.7 & 72.0 \\
\hline Scenario 4 & 49.5 & $\$ 1.46$ & $\$ 1.24$ & 111.0 & 72.3 \\
\hline Scenario 5a & 43.8 & $\$ 1.68$ & $\$ 1.42$ & 112.2 & 73.6 \\
\hline Scenario 5b & 43.6 & $\$ 1.36$ & $\$ 1.13$ & 98.1 & 59.2 \\
\hline Scenario 6 & 45 & $\$ 1.63$ & $\$ 1.38$ & 110.5 & 80.0 \\
\hline Scenario 7 & 49 & $\$ 1.51$ & $\$ 1.29$ & 107.7 & 80.9 \\
\hline
\end{tabular}

Table 15. Sensitivity Results of Selling Solids with Evaporators Removed (soluble solids to WWT)

\begin{tabular}{|c|c|c|c|c|c|}
\hline Evaporators Removed & $\begin{array}{c}\text { Annual Ethanol } \\
\text { Output (MMGal) }\end{array}$ & $\begin{array}{c}\text { Annual Ethanol } \\
\text { Production Cost } \\
(\$ / g a l)\end{array}$ & $\begin{array}{c}\text { Net Operating } \\
\text { Cost (\$/gal) }\end{array}$ & $\begin{array}{c}\text { Total Capital } \\
\text { Investment } \\
(\mathrm{MM} \$)\end{array}$ & $\begin{array}{c}\text { Operating Costs } \\
(\mathrm{MM} \$ \mathbf{y r})\end{array}$ \\
\hline Scenario 3 & 50 & $\$ 1.36$ & $\$ 1.05$ & 154.3 & 68.0 \\
\hline Stover Plant & 50 & $\$ 1.45$ & $\$ 1.06$ & 193.7 & 72.0 \\
\hline Scenario 4 & 49.5 & $\$ 1.41$ & $\$ 1.20$ & 102.9 & 69.8 \\
\hline Scenario 5a & 43.8 & $\$ 1.54$ & $\$ 1.31$ & 102.1 & 67.5 \\
\hline Scenario 5b & 43.6 & $\$ 1.33$ & $\$ 1.11$ & 93.8 & 57.9 \\
\hline Scenario 6 & 45 & $\$ 1.53$ & $\$ 1.31$ & 102.0 & 68.8 \\
\hline Scenario 7 & 49 & $\$ 1.42$ & $\$ 1.22$ & 99.2 & 69.7 \\
\hline
\end{tabular}

On production cost alone, only one of the sensitivities (5b) compares favorably to the best scenario where the solids are not combined. However, three of the sensitivities compare favorably to a stand alone 50 million annual gallon stover plant (4, 5b \& 7). The capital costs are significantly reduced in some cases but the determining factors are the operating costs, driven by the natural gas price used $(\$ 4 / \mathrm{Mbtu})$ and the loss of ethanol production in cases where the C5 sugars are not fermented.

Another sensitivity was run to see at what diminished DDGS selling price would the bestcase scenario where the co-products are kept separate have to be in order to "break even" with a combined coproduct scenario. The following figure shows a sensitivity of the annual ethanol production cost (AEPC) as a function of the combined solids selling price for the combined ethanol purification scenario. The results show that there are some scenarios that cannot compare to this scenario even if the DDGS selling price was $\$ 0$. Comparing this chart to Table 14, the selling price of DDGS must be around $\$ 25 /$ ton for 
scenarios 4 and 7 to compare favorably. This is close to a 70\% drop in DDGS value. The DDGS value must diminish even further to compare with a stand alone stover plant.

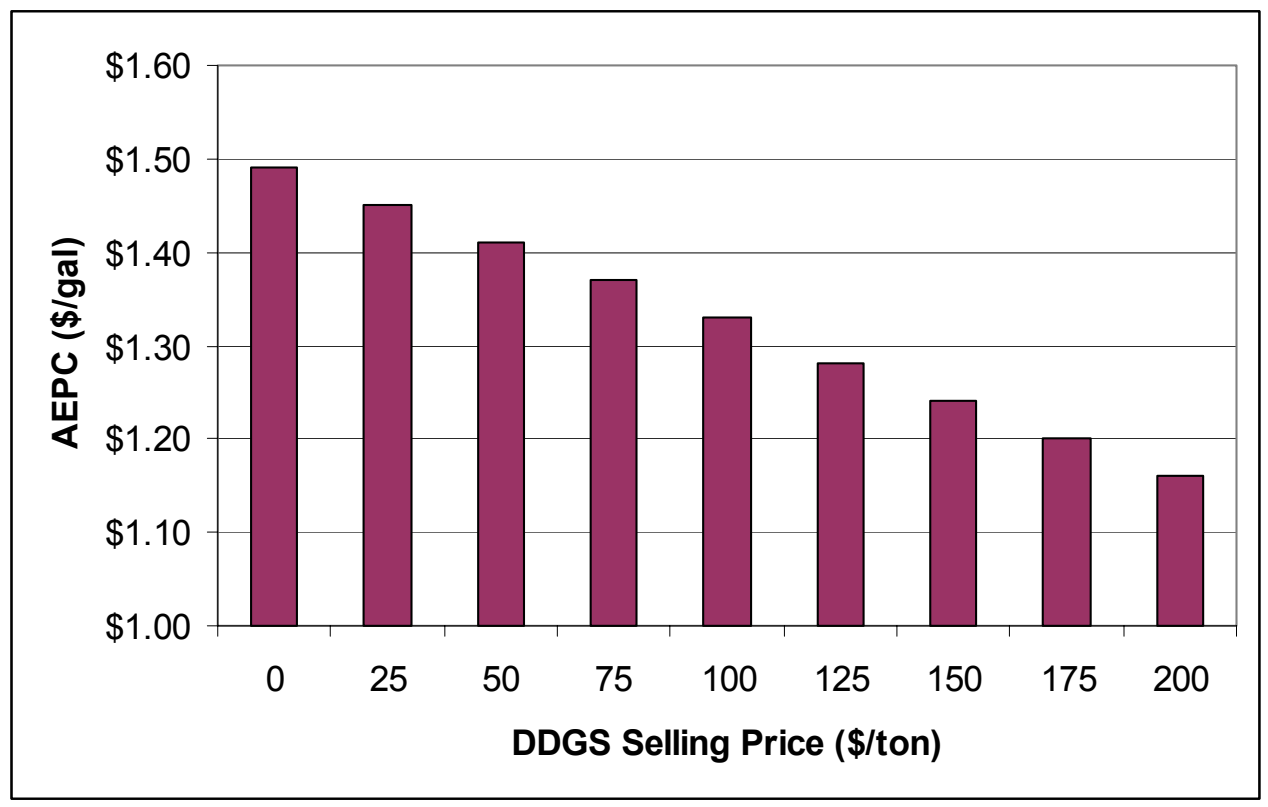

Figure 11. DDGS Selling Price Sensitivity

Other sensitivities were run on the cost of corn stover and the cost per gallon of the cellulase enzyme. The NREL 2002 design report mentioned earlier assumes a delivered corn stover price of $\$ 30 / \mathrm{bdt}$ and a purchased enzyme cost of $\$ 0.10 /$ gal ethanol produced. These values are in line with the nth plant assumption used by NREL. 


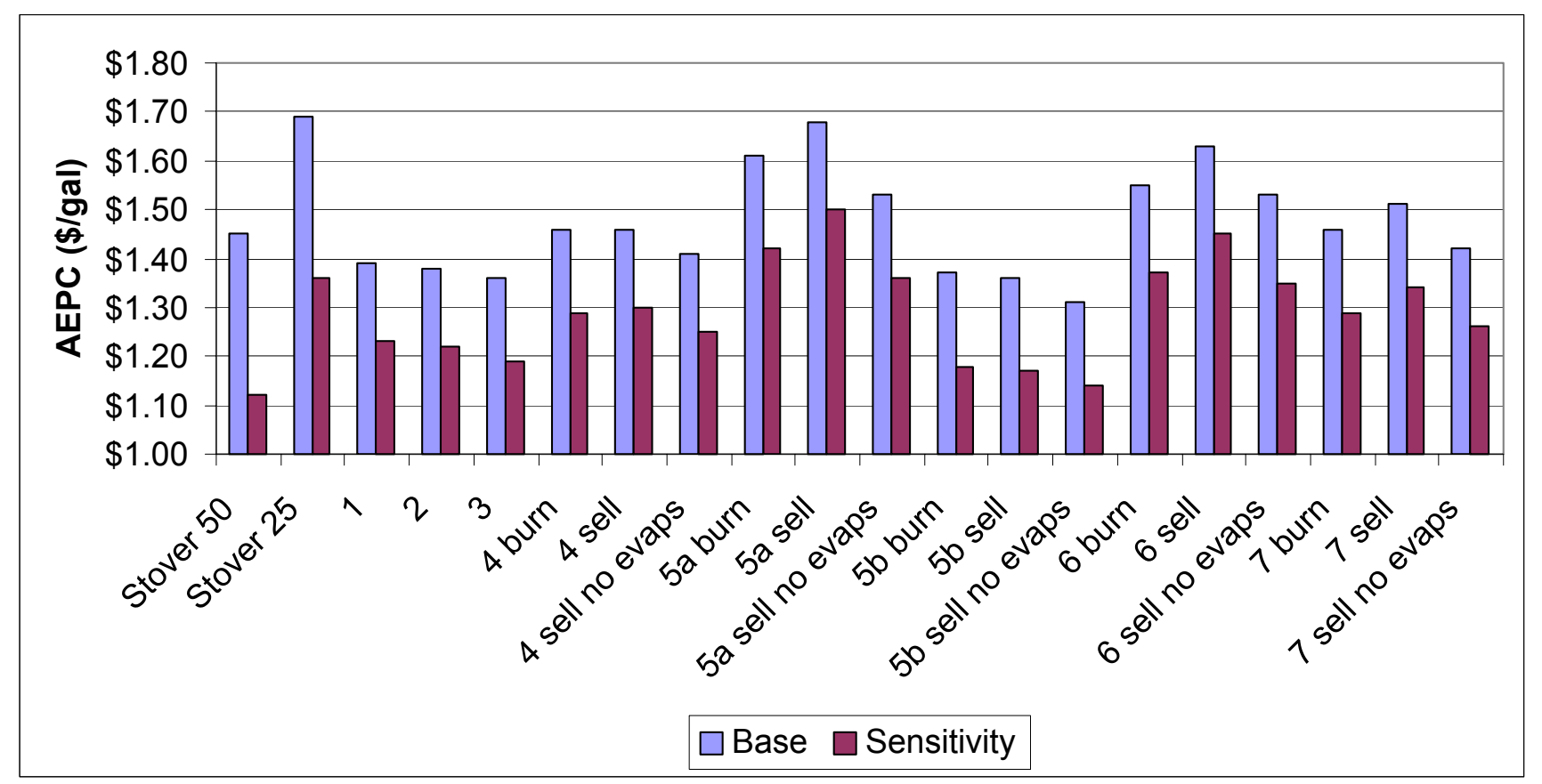

Figure 12. nth Plant Feedstock and Enzyme Cost Sensitivity

Figure 12 shows that by assuming an nth plant cost for delivered stover and purchased cellulase enzymes, there is a large savings compared to the current values being used. Therefore, if the enzyme companies currently under contract with DOE succeed in lowering the purchased enzyme cost and feedstock harvesting and delivery methods are improved, significant economic improvements can be realized making the stover to ethanol concept a more attractive option.

\section{VII: Conclusions}

Under the assumptions used in this study, there are cases where economic benefit by colocating a corn starch and stover plant together can be realized. Combining utilities, combining ethanol purification and combining C6 fermentation while selling the C5 stream realize an economic benefit to a stand alone 50 million gallon stover to ethanol plant, but are still less promising from an economic view than the stand alone 50 million gallon corn starch to ethanol plant.

Using 2002 price indices, natural gas at \$4/MMBtu does not significantly affect the bottom line. However, current natural gas prices are around $\$ 6 / \mathrm{MMBtu}$. The rising price of natural gas has a large negative impact on the profitability of the cases where a natural gas boiler is installed instead of a FBC. At \$6/MMBtu, the economics are not favorable for any case where a NGB is utilized. The concern with rising natural gas prices has forced some dry millers to investigate using a biomass boiler in place of a natural gas boiler. 
This study highlighted the importance of DDGS or some other high value co-product for ethanol production from both corn and lignocellulosic feedstocks. It also demonstrated the importance of converting all the carbohydrates in stover to ethanol.

The analysis also suggests qualitative benefits. A facility built to process both corn and lignocellulosic feedstocks has flexibility to process one or both depending on the best value feed. Installing a Fluidized Bed Combustor creates flexibility in fuel options, from natural gas, biomass, and coal. The required radius of transportation decreases when stover is used in ethanol production.

In 1998, DOE provided funds to allow corn ethanol producers to investigate the possibilities for producing ethanol from lignocellulose at their facilities. Five companies from the industry teamed with engineering construction firms and other professionals to explore the potential of co-location of cellulosic ethanol with their existing corn ethanol processes. A list of the "Bridge To Corn Ethanol" project participants and their reports are listed below.

- NYSTEC/Robbins Corn/Raytheon http://devafdc.nrel.gov/pdfs/4912.pdf

- Vogelbusch/Chief Ethanol/ KAPPA http://devafdc.nrel.gov/pdfs/4575.pdf

- Merrick and Company/High Plains Ethanol/Pure Vision Technologies http://devafdc.nrel.gov/pdfs/4351.pdf

- LORRE/Williams Bioenergy/USDA NCAUR http://devafdc.nrel.gov/pdfs/3594.pdf

- Swan Biomass http://devafdc.nrel.gov/pdfs/4907.pdf

One project with corn fiber as the feedstock returned a competitive ethanol production cost. All of the projects involving corn stover use at a dry mill were deemed unprofitable, with negative or zero return on investment. With reduced enzyme costs, at least one of the corn stover projects would be profitable and potentially a second. The complete reports are available through NREL. From this work, it was decided that for a collocation to be successful a green-field site had to be considered. However, even this option would have hurdles to overcome. The following challenges exist for collocation:

1) Develop a robust multi-sugar ethanologen. If genetically modified, gain acceptance of genetically modified organism use.

2) Find a high value use for the lignin.

3) Reduce the capital investment for stover processing.

\section{VIII: Ongoing Projects}

There are several projects underway to demonstrate cellulose conversion technology in conjunction with starch processing. They span a range of products and feeds, from ethanol to chemicals and stover to corn fiber. A few are discussed here. 


\section{Dupont Integrated Corn-based Biorefinery}

The Dupont project, established in 2003, is a four-year research project that will provide a technical foundation for DuPont's proposed Integrated Corn-based Biorefinery. Participants in this project are DuPont, Diversa, John Deere, Michigan State University, and NREL. The objectives of the NREL work is to develop a corn stover/fiber pretreatment scheme and microbial biocatalysts that integrate with enzymatic saccharification. NREL's role includes pretreatment, chemical analysis, and strain development. The pretreatment efforts involve the development of a mild pretreatment approach and will be developed in concert with Diversa's enzyme discovery and development efforts. The pretreatment effort will involve a bench scale program, including development of rapid chemical analysis methods specifically for these pretreated feedstocks, followed by scale up in NREL's PDU and eventually, to a dedicated semi works facility built and operated by DuPont. The strain development efforts involve the collaboration of scientists and engineers at DuPont and NREL to generate a superior ethanologenic Zymomonas mobilis. The work is scheduled to be performed over a four-year period, between 2003 and 2007.

\section{Cargill-Dow's Making the Biorefinery Happen}

This project will develop and validate process technology and sustainable agricultural systems to economically produce sugars and chemicals such as lactic acid and ethanol.

\section{Cargill's New Biorefinery Platform Intermediate}

This project will develop a biobased technology to produce a wide variety of products based on 3-hydroxypropionic acid (3-HP), which is produced by fermentation of carbohydrates.

\section{Corn Ethanol Production Improvement}

The objective of this project area is to identify advanced technologies that will improve the profitability of corn based fuel ethanol and chemical production, making it more competitive with petroleum based technologies. Over the years, ethanol producers have adopted various technologies such as high tolerance yeasts, continuous ethanol fermentation, co-generation of steam and electricity, and molecular sieve driers to reduce ethanol production costs.

\section{USDA-ARS ERRC and Michigan Biotechnology Institute}

New technologies for corn utilization are being developed and tested for their economic and technical viability by USDA, University of Illinois, Michigan Biotechnology Institute (MBI), and until recently, NREL. Corn fiber can be separated from the starch component prior to processing utilizing a liquid soaking process or by mechanical de-germing processes. The fibrous residue can then be converted into various products, including additional ethanol via pretreatment followed by saccharification and fermentation. This 
process could improve the economics of a dry mill operation by increasing the amount of ethanol produced from the extracted fiber and lead to the development of new coproducts including a higher protein content animal feed.

\section{Broin 2nd Generation Dry Mill Biorefinery}

The Broin project is a continuation of ongoing efforts to develop new technologies to improve the efficiency of U.S. ethanol production. In the past, Broin \& Associates and NREL focused on developing improvements in process throughput and water management for dry mill ethanol plants, evaluating proprietary yeast strains developed by NREL for improving ethanol yields and, completing an overall process engineering model of the dry mill technology that identifies new ways to increase efficiencies and improve economics.

In 2003, Broin began researching and developing a dry mill "biorefinery" for enhancing the economics of existing ethanol dry mills by creating additional co-products and increasing ethanol yields by fractionation of the bran, germ, and endosperm in the incoming corn feed using proprietary processes and equipment. The objectives of the NREL work within the contract will be to develop a conversion scheme to increase the total value of second-generation dry mill products.

\section{Abengoa Advanced Biorefining of Distiller's Grain \& Corn Stover Blends}

The goal of the Abengoa project, a collaboration between NREL, Abengoa Bioenergy Corporation and Novozymes North America, Inc., is to develop process technology that utilizes advanced biorefining techniques to improve dry mill efficiency and profitability. It will also continue to build the bridge between starch and lignocellulose conversion.

This technology will enable a more economical, sustainable industry and will achieve significant additional petroleum displacement by decreasing the process petroleum use per gallon of ethanol produced and increasing overall ethanol production and availability. In FY03, this project will complete a preliminary investigation of process options, make significant progress towards demonstrating pretreatment at the bench scale, and begin developing an applicable rapid analysis method. The ultimate goal is to combine novel technologies into one conversion process that will be tested through Abengoa's pilot and demonstration facilities in 2004-2006 accelerating the success of the technologies.

\section{Other corn ethanol improvement projects:}

\section{Iowa Corn Promotion Board's Value Added Products from hemicellulose Utilization in Dry Mill Ethanol Plants}

This proposal is aimed at conversion of hemicellulose into high-value products. Successful completion of this project will lead to value-added products from dry mill corn ethanol facilities and will improve the overall economics of ethanol production. As 
more dry mill ethanol facilities begin production, this technology will help develop new products to diversify the dry mill business.

\section{National Corn Grower's Association's Separation of Corn Fiber \& Conversion to Fuels \& Chemicals}

This project will develop an integrated process for recovery of the hemicellulose, protein, and oil components from corn fiber for conversion into value-added products.

${ }^{\mathrm{i}}$ Building a Bridge to the Corn Ethanol Industry, NREL Subcontract ZXE-9-18080-01. Work performed by Vogelbusch U.S.A. Inc., Houston, TX, January 10, 2000.

ii Building a Bridge to the Corn Ethanol Industry, NREL Subcontract ZXE-9-18080-05. Work performed by New York State Technology Enterprise Corporation, Rome, NY, December 31, 1999.

iii Building a Bridge to the Corn Ethanol Industry, NREL Subcontract ZXE-9-18080-04. Work performed by Merrick \& Company, Aurora, CO, January, 2000.

${ }^{\text {iv }}$ Faust, et.al; Roadmap for Agricultural Biomass Feedstock in the United States, November 2003

v Watson, S.; Ramstad, P.; Corn: Chemistry and Technology, 1987, American Association of Cereal Chemists, Inc., St. Paul, MN

vi Stover composition is an average of several samples collected from various regions and seasons, normalized with a soluble solids component that is considered similar to extractives. This is the composition used in the NREL design case for stover.

vii Aden, et.al, Lignocellulosic Biomass to Ethanol Process Design and Economics Utilizing Cocurrent dilute Acid Prehydrolysis and Enzymatic Hydrolysis for Corn Stover. National Renewable Energy Laboratory, Golden, CO, May, 2002.

viii Distillers Grains Technology Council brochure. 
Appendix A:

MS Excel Summary Sheets for Base Case ASPEN Models 
USDA 25 Million gallon Corn starch to Ethanol

\title{
Shelled Corn to Ethanol Process Analysis
}

Dry Grind Starch Fermentation

All Values in 2002 Dollars

\section{Annual Ethanol Production Cost\$1.02 Per Gallon}

\author{
Fuel Ethanol Production (MM Gal. / Year) 25.0 Ethanol at $68^{\circ} \mathrm{F}$ \\ Ethanol Yield (Gal / Bushel Corn) $\quad 2.84$ \\ Feedstock Cost (\$/Bushel) \$2.25 15\% Moisture Content
}

\begin{tabular}{lr}
\multicolumn{2}{c}{ Variables } \\
\hline Cost Year for Analysis & 2002 \\
Life of Equipment & 10 \\
Days of Operation per Year & 330 \\
$\%$ Denaturant in Final Fuel Ethanol & $5.0 \%$ \\
Feedstock Cost \$/ Bushel & $\$ 2.25$ \\
DDGS Price \$/ton & $\$ 80.00$
\end{tabular}

Installed Capital Costs

$\$ 31,700,000$
Operating Costs (\$/gal ethanol)

\begin{tabular}{lr}
\hline Shelled Corn & $\$ 0.793$ \\
Denaturant & $\$ 0.026$ \\
Other Raw Materials & $\$ 0.073$ \\
Utilities & $\$ 0.170$ \\
Labor, Supplies and Overheads & $\$ 0.099$ \\
Depreciation & $\$ 0.127$ \\
CoProduct Credits & $-\$ 0.263$ \\
\cline { 2 - 2 } Total Product Cost per gallon & $\$ 1.023$
\end{tabular}

\section{Operating Costs (Million $\$ / y r$ )}

\begin{tabular}{lr}
\hline Shelled Corn & $\$ 19,800,000$ \\
Denaturant & $\$ 600,000$ \\
Other Raw Materials & $\$ 1,800,000$ \\
Utilities & $\$ 4,200,000$ \\
Labor, Supplies and Overheads & $\$ 2,500,000$ \\
Depreciation & $\$ 3,200,000$ \\
CoProduct Crdits & $-\$ 6,600,000$ \\
Total Production Cost & $\$ 25,600,000$
\end{tabular}




\section{USDA 50 Million gallon Corn starch to Ethanol}

\section{Shelled Corn to Ethanol Process Analysis}

Dry Grind Starch Fermentation

All Values in 2002 Dollars

\section{Annual Ethanol Production Cost\$0.96 Per Gallon}

Fuel Ethanol Production (MM Gal. / Year) Ethanol Yield (Gal / Bushel Corn) Feedstock Cost (\$/Bushel)
50.0 Ethanol at $68^{\circ} \mathrm{F}$

2.84

$\$ 2.2515 \%$ Moisture Content

\begin{tabular}{lr}
\multicolumn{2}{c}{ Variables } \\
\hline Cost Year for Analysis & 2002 \\
Life of Equipment & 10 \\
Days of Operation per Year & 330 \\
$\%$ Denaturant in Final Fuel Ethanol & $5.0 \%$ \\
Feedstock Cost \$ Bushel & $\$ 2.25$ \\
DDGS Price \$/ton & $\$ 80.00$
\end{tabular}

Installed Capital Costs

$\$ 48,000,000$
Operating Costs (\$/gal ethanol)

\begin{tabular}{lr}
\hline Shelled Corn & $\$ 0.793$ \\
Denaturant & $\$ 0.026$ \\
Other Raw Materials & $\$ 0.073$ \\
Utilities & $\$ 0.167$ \\
Labor, Supplies and Overheads & $\$ 0.064$ \\
Depreciation & $\$ 0.096$ \\
CoProduct Credits & $-\$ 0.263$ \\
\cline { 2 - 2 } Total Product Cost per gallon & $\$ 0.955$
\end{tabular}

\begin{tabular}{lr}
\multicolumn{2}{c}{ Operating Costs (/yr) } \\
\hline Shelled Corn & $\$ 39,700,000$ \\
Denaturant & $\$ 1,300,000$ \\
Other Raw Materials & $\$ 3,600,000$ \\
Utilities & $\$ 8,400,000$ \\
Labor, Supplies and Overheads & $\$ 3,200,000$ \\
Depreciation & $\$ 4,800,000$ \\
CoProduct Crdits & $\mathbf{\$ 1 3 , 2 0 0 , 0 0 0}$ \\
${ } }$ & $\$ 47,800,000$
\end{tabular}




\title{
NREL 25 Million Gallon Corn Stover to Ethanol \\ Ethanol Production Process Engineering Analysis
}

\author{
All Values in $2002 \$$
}

\section{Annual Ethanol Production Cost\$1.76 Per Gallon \\ Net Operating Cost\$1.28 Per Gallon \\ Fuel Ethanol Production (MM Gal. / Year)25 \\ Ethanol at $68^{\circ} \mathrm{F}$}

Fuel Ethanol Yield (Gal / Dry US Ton Feedstock)79.2

Feedstock Cost $\$ /$ Dry US Ton $\$ 40$

\begin{tabular}{lr}
\multicolumn{2}{c}{ Variables } \\
\hline Cost Year for Analysis & 2002 \\
Life of Equipment & 10 \\
Days of Operation per Year & 330 \\
$\%$ Denaturant in Final Fuel Ethanol & $5 \%$ \\
Feedstock Cost \$/Dry US Ton & $\$ 40$
\end{tabular}

\begin{tabular}{lr}
\multicolumn{2}{c}{ Capital Costs } \\
\hline Feed Handling & $\$ 6,700,000$ \\
Pretreatment & $\$ 13,900,000$ \\
Neutralization/Conditioning & $\$ 10,900,000$ \\
Saccharification \& Fermentation & $\$ 19,200,000$ \\
Distillation and Solids Recovery & $\$ 23,500,000$ \\
Wastewater Treatment & $\$ 2,100,000$ \\
Storage & $\$ 2,100,000$ \\
Boiler/Turbogenerator & $\$ 36,700,000$ \\
Utilities & $\$ 5,500,000$ \\
Total Capital Investment & $\$ 120,700,000$
\end{tabular}

\begin{tabular}{lr}
\multicolumn{2}{c}{ Operating Costs (\$/gal ethanol) } \\
\hline Feedstock & 0.51 \\
CSL & 0.03 \\
Cellulase & 0.30 \\
Other Raw Materials & 0.07 \\
Waste Disposal & 0.04 \\
Electricity & -0.13 \\
Fixed Costs & 0.34 \\
Denaturant & 0.02 \\
Capital Depreciation & $\underline{0.48}$ \\
Total Product Cost per Gallon & 1.69 \\
\multicolumn{1}{c}{ Operating Costs $(\$ / y r)$} \\
\hline Feedstock & $\$ 12,700,000$ \\
CSL & $\$ 800,000$ \\
Cellulase & $\$ 7,600,000$ \\
Other Raw Matl. Costs & $\$ 3,400,000$ \\
Denaturant & $\$ 600,000$ \\
Waste Disposal & $\$ 900,000$ \\
Electricity & $-\$ 2,700,000$ \\
Fixed Costs & $\$ 8,500,000$ \\
Capital Depreciation & $\$ 12,100,000$ \\
Total Annual Production Cost & $43,900,000$
\end{tabular}




\section{NREL 50 Million Gallon Corn Stover to Ethanol \\ Ethanol Production Process Engineering Analysis}

Dilute Acid Prehydrolysis with Saccharification and Co-Fermentation

All Values in $2002 \$$

\section{Annual Ethanol Production Cost\$1.45 Per Gallon \\ Net Operating Cost\$1.06 Per Gallon \\ Fuel Ethanol Production (MM Gal. / Year) 50 \\ Ethanol at $68^{\circ} \mathrm{F}$}

Fuel Ethanol Yield (Gal / Dry US Ton Feedstock)79.2

Feedstock Cost $\$ /$ Dry US Ton $\$ 40$

\begin{tabular}{lr}
\multicolumn{2}{c}{ Variables } \\
\hline Cost Year for Analysis & 2002 \\
Life of Equipment & 10 \\
Days of Operation per Year & 330 \\
$\%$ Denaturant in Final Fuel Ethanol & $5 \%$ \\
Feedstock Cost \$/Dry US Ton & $\$ 40$
\end{tabular}

\begin{tabular}{lr}
\multicolumn{2}{c}{ Capital Costs } \\
\hline Feed Handling & $\$ 10,500,000$ \\
Pretreatment & $\$ 21,300,000$ \\
Neutralization/Conditioning & $\$ 16,600,000$ \\
Saccharification \& Fermentation & $\$ 20,400,000$ \\
Distillation and Solids Recovery & $\$ 37,200,000$ \\
Wastewater Treatment & $\$ 2,900,000$ \\
Storage & $\$ 3,200,000$ \\
Boiler/Turbogenerator & $\$ 73,300,000$ \\
Utilities & $\$ 8,100,000$ \\
Total Capital Investment & $\$ 193,700,000$
\end{tabular}

\begin{tabular}{lr}
\multicolumn{2}{c}{ Operating Costs (\$/gal ethanol) } \\
\hline Feedstock & 0.51 \\
CSL & 0.03 \\
Cellulase & 0.30 \\
Other Raw Materials & 0.06 \\
Waste Disposal & 0.04 \\
Electricity & -0.13 \\
Fixed Costs & 0.22 \\
Denaturant & 0.02 \\
Capital Depreciation & $\underline{0.39}$ \\
Total Product Cost per Gallon & 1.45 \\
& \\
\hline \multicolumn{1}{c}{ Operating Costs $(\$ / y r)$} \\
Feedstock & $\$ 25,400,000$ \\
CSL & $\$ 1,600,000$ \\
Cellulase & $\$ 15,100,000$ \\
Other Raw Matl. Costs & $\$ 3,200,000$ \\
Denaturant & $\$ 1,200,000$ \\
Waste Disposal & $\$ 1,800,000$ \\
Electricity & $\$ 1,500,000$ \\
Fixed Costs & $\$ 10,800,000$ \\
Capital Depreciation & $\$ 19,400,000$ \\
Total Annual Production Cost & $72,000,000$
\end{tabular}




\section{Combined 50 Million gallon Facility (Scenario 1) \\ Ethanol Production Process Engineering Analysis}

Dilute Acid Prehydrolysis with Saccharification and Co-Fermentation

\section{Annual Ethanol Production Cost Net Operating Cost \\ Fuel Ethanol Production (MM Gal. / Year) \\ Fuel Ethanol Yield (Gal / Dry US Ton Feedstock) \\ Feedstock Cost \$/Dry US Ton \\ Ethanol Yield (Gal / Bushel Corn)}

\begin{tabular}{lr}
\multicolumn{2}{c}{ Variables } \\
\hline Cost Year for Analysis & 2002 \\
Life of Equipment & 10 \\
Days of Operation per Year & 330 \\
\% Denaturant in Final Fuel Ethanol & $5 \%$ \\
Feedstock Cost \$/Dry US Ton & $\$ 40$ \\
Feedstock Cost \$/ Bushel & $\$ 2.25$ \\
DDGS Price \$/ton & $\$ 80.00$
\end{tabular}

\begin{tabular}{lr}
\multicolumn{2}{c}{ Capital Costs } \\
\hline Feed Handling & $\$ 6,700,000$ \\
Pretreatment & $\$ 14,000,000$ \\
Neutralization/Conditioning & $\$ 10,900,000$ \\
Saccharification \& Fermentation & $\$ 19,200,000$ \\
Distillation and Solids Recovery & $\$ 23,500,000$ \\
Wastewater Treatment & $\$ 2,100,000$ \\
Storage & $\$ 2,100,000$ \\
Boiler/Turbogenerator & $\$ 36,600,000$ \\
Utilities & $\$ 5,500,000$ \\
Total Stover Capital Investment & $\$ 120,600,000$ \\
& \\
Total Starch Capital Investment & $\$ 31,100,000$ \\
Total Combined Capital Investment & $\$ 151,700,000$
\end{tabular}

$\$ 1.39$ Per Gallon

\section{\$1.09 Per Gallon}

50

79.2

$\$ 40$

2.84

\section{Ethanol at $68^{\circ} \mathrm{F}$}

Shelled Corn

Biomass Feedstock

Operating Costs (\$/gal ethanol)

CSL

Cellulase

0.26

0.02
0.15

Other Raw Materials $\quad 0.09$

Waste Disposal $\quad 0.02$

Electricity $\quad-0.07$

Fixed Costs $\quad 0.26$

Denaturant 0.02

DDG Co-product $\quad-0.13$

Starch Utilities $\quad 0.08$

Capital Depreciation $\quad \underline{0.30}$

Total Product Cost per Gallon

\begin{tabular}{lr}
\multicolumn{2}{c}{ Operating Costs $(\$ / y r)$} \\
\hline Shelled Corn \\
Biomass Feedstock & $\$ 19,800,000$ \\
CSL & $\$ 12,700,000$ \\
Cellulase & $\$ 800,000$ \\
Other Raw Matl. Costs & $\$ 7,600,000$ \\
Denaturant & $\$ 4,300,000$ \\
Waste Disposal & $\$ 1,200,000$ \\
Electricity & $\$ 900,000$ \\
DDG Co-product & $-\$ 3,400,000$ \\
Starch Utilities & $-\$ 6,500,000$ \\
Fixed Costs & $\$ 4,100,000$ \\
Capital Depreciation & $\$ 12,800,000$ \\
Total Annual Production Cost & $\$ 15,200,000$ \\
\hline
\end{tabular}




\section{Scenario 2: Combined Utilities}

Ethanol Production Process Engineering Analysis

Dilute Acid Prehydrolysis with Saccharification and Co-Fermentation

\section{Annual Ethanol Production Cost}

\section{Net Operating Cost}

Fuel Ethanol Production (MM Gal. / Year)

Fuel Ethanol Yield (Gal / Dry US Ton Feedstock)

Feedstock Cost \$/Dry US Ton

Ethanol Yield (Gal / Bushel Corn)

\begin{tabular}{lr} 
& \\
\hline Cost Year for Analysis & 2002 \\
Life of Equipment & 10 \\
Days of Operation per Year & 330 \\
\% Denaturant in Final Fuel Ethanol & $5 \%$ \\
Feedstock Cost \$/Dry US Ton & $\$ 40$ \\
Feedstock Cost \$/ Bushel & $\$ 2.25$ \\
DDGS Price \$/ton & $\$ 80.00$
\end{tabular}

\begin{tabular}{lr}
\multicolumn{2}{c}{ Capital Costs } \\
\hline Feed Handling & $\$ 6,700,000$ \\
Pretreatment & $\$ 13,900,000$ \\
Neutralization/Conditioning & $\$ 10,900,000$ \\
Saccharification \& Fermentation & $\$ 19,200,000$ \\
Distillation and Solids Recovery & $\$ 23,500,000$ \\
Wastewater Treatment & $\$ 2,200,000$ \\
Storage & $\$ 2,100,000$ \\
Boiler/Turbogenerator & $\$ 44,800,000$ \\
Utilities & $\$ 7,300,000$ \\
Total Stover Capital Investment & $\$ 130,600,000$
\end{tabular}

Total Starch Capital Investment

$\$ 29,300,000$

Total Combined Capital Investment
All Values in $2002 \$$

\section{$\$ 1.38$ Per Gallon \\ $\$ 1.06$ Per Gallon \\ $50 \quad$ Ethanol at $68^{\circ} \mathrm{F}$ \\ 79.2 \\ $\$ 40$}

Operating Costs (\$/gal ethanol)

Shelled Corn

0.40

0.26

CSL

Cellulase

Other Raw Materials

Waste Disposal 0.02

\begin{tabular}{lr} 
Electricity & 0.02 \\
\hline
\end{tabular}

Fixed Costs $\quad 0.26$

Denaturant $\quad 0.02$

DDG Co-product $\quad-0.13$

Starch Utilities $\quad 0.00$

Capital Depreciation $\quad \underline{0.32}$

Total Product Cost per Gallon

\begin{tabular}{ll}
\multicolumn{2}{c}{ Operating Costs $(\$ / y r)$} \\
\hline Shelled Corn & $\$ 19,800,000$
\end{tabular}

Biomass Feedstock $\$ \$ 12,700,000$

CSL $\$ \$ 800,000$

Cellulase $\quad \$ 7,600,000$

Other Raw Matl. Costs \$ \$6,700,000

Denaturant $\$ 1,200,000$

Waste Disposal $\quad \$ 1,000,000$

Electricity $\quad-\$ 3,000,000$

DDG Co-product $\quad-\$ 6,500,000$

Starch Utilities $\$ 0$

Fixed Costs $\$ 13,000,000$

Capital Depreciation $\$ \$ 16,000,000$

Total Annual Production Cost $\quad \frac{\$ 16,000,000}{69,300,000}$ 


\section{Scenario 3: Combined Ethanol Purification \\ Ethanol Production Process Engineering Analysis}

Dilute Acid Prehydrolysis with Saccharification and Co-Fermentation

$\begin{array}{lc}\text { Annual Ethanol Production Cost } & \text { All Values in } 2002 \$ \\ \text { Net Operating Cost } & \$ 1.36 \\ \text { Fuel Ethanol Production (MM Gal. / Year) } & \$ 1.05 \\ \text { Fuel Ethanol Yield (Gal / Dry US Ton Feedstock) } & 50 \\ \text { Feedstock Cost \$/Dry US Ton } & 79.5 \\ \text { Ethanol Yield (Gal / Bushel Corn) } & \$ 40 \\ & 2.84\end{array}$

$\begin{array}{ll}\$ 1.36 & \text { Per Gallon } \\ \mathbf{\$ 1 . 0 5} & \text { Per Gallon } \\ 50 & \text { Ethanol at } 68^{\circ} \mathrm{F} \\ 79.5 & \end{array}$

Ethanol Yield (Gal / Bushel Corn)

Variables

\begin{tabular}{|c|c|c|c|}
\hline \multicolumn{2}{|c|}{ Variables } & \multirow{2}{*}{$\begin{array}{l}\text { Biomass Feedstock } \\
\text { CSL }\end{array}$} & 0.25 \\
\hline Cost Year for Analysis & 2002 & & 0.02 \\
\hline Life of Equipment & 10 & Cellulase & 0.15 \\
\hline Days of Operation per Year & 330 & Other Raw Materials & 0.13 \\
\hline \% Denaturant in Final Fuel Ethanol & $5 \%$ & Waste Disposal & 0.02 \\
\hline Feedstock Cost $\$ /$ Dry US Ton & $\$ 40$ & Electricity & -0.06 \\
\hline Feedstock Cost $\$$ / Bushel & $\$ 2.25$ & Fixed Costs & 0.25 \\
\hline \multirow[t]{2}{*}{ DDGS Price \$/ton } & $\$ 80.00$ & Denaturant & 0.02 \\
\hline & & DDG Co-product & -0.13 \\
\hline \multicolumn{2}{|l|}{ Capital Costs } & Starch Utilities & 0.00 \\
\hline Feed Handling & $\$ 6,700,000$ & Capital Depreciation & $\underline{0.31}$ \\
\hline Pretreatment & $\$ 13,900,000$ & Total Product Cost per Gallon & 1.36 \\
\hline Neutralization/Conditioning & $\$ 10,900,000$ & \multicolumn{2}{|c|}{ Operating Costs $(\$ / y r)$} \\
\hline Saccharification \& Fermentation & $\$ 19,200,000$ & Shelled Corn & $\$ 19,800,000$ \\
\hline Distillation and Solids Recovery & $\$ 26,300,000$ & Feedstock & $\$ 12,700,000$ \\
\hline Wastewater Treatment & $\$ 2,200,000$ & CSL & $\$ 800,000$ \\
\hline Storage & $\$ 2,700,000$ & Cellulase & $\$ 7,600,000$ \\
\hline Boiler/Turbogenerator & $\$ 43,200,000$ & Other Raw Matl. Costs & $\$ 6,500,000$ \\
\hline Utilities & $\$ 6,700,000$ & Denaturant & $\$ 1,200,000$ \\
\hline \multirow[t]{3}{*}{ Total Stover Capital Investment } & $\$ 131,800,000$ & Waste Disposal & $\$ 1,000,000$ \\
\hline & & Electricity & $-\$ 2,900,000$ \\
\hline & & Fixed Costs & $\$ 12,400,000$ \\
\hline \multirow[t]{3}{*}{ Total Starch Capital Investment } & $\$ 22,500,000$ & DDG Co-product & $-\$ 6,500,000$ \\
\hline & & Starch Utilities & $\$ 0$ \\
\hline & & Capital Depreciation & $\$ 15,400,000$ \\
\hline Total Combined Capital Investment & $\$ 154,300,000$ & Total Annual Production Cost & $68,000,000$ \\
\hline
\end{tabular}




\section{Scenario 4: Combined Product Processing Ethanol Production Process Engineering Analysis}

Dilute Acid Prehydrolysis with Saccharification and Co-Fermentation All Values in $2002 \$$

Annual Ethanol Production Cost Net Operating Cost

Fuel Ethanol Production (MM Gal. / Year)

Fuel Ethanol Yield (Gal / Dry US Ton Feedstock)

Feedstock Cost \$/Dry US Ton

Ethanol Yield (Gal / Bushel Corn)

\begin{tabular}{lr} 
& Variables \\
\hline Cost Year for Analysis & 2002 \\
Life of Equipment & 10 \\
Days of Operation per Year & 330 \\
\% Denaturant in Final Fuel Ethanol & $5 \%$ \\
Feedstock Cost \$/Dry US Ton & $\$ 40$ \\
Feedstock Cost \$/ Bushel & $\$ 2.25$ \\
DDGS Price \$/ton & $\$ 80.00$ \\
& \\
\hline$\quad$ Feed Handling & \\
$\quad$ Pretreatment & $\$ 6,700,000$ \\
$\quad$ Neutralization/Conditioning Costs & $\$ 13,900,000$ \\
$\quad$ Saccharification \& Fermentation & $\$ 10,900,000$ \\
$\quad$ Distillation and Solids Recovery & $\$ 19,200,000$ \\
$\quad$ Wastewater Treatment & $\$ 31,400,000$ \\
$\quad$ Storage & $\$ 2,200,000$ \\
$\quad$ Boiler/Turbogenerator & $\$ 2,600,000$ \\
$\quad$ Utilities & $\$ 44,300,000$ \\
Total Stover Capital Investment & $\$ 6,500,000$ \\
$\quad$ & $\$ 137,800,000$ \\
Total Starch Capital Investment & \\
& $\$ 9,600,000$ \\
Total Combined Capital Investment & \\
\end{tabular}

$\$ 1.46$ Per Gallon

$\$ 1.16$ Per Gallon

$49.48 \quad$ Ethanol at $68^{\circ} \mathrm{F}$

77.9

$\$ 40$

2.84

\begin{tabular}{lr}
\multicolumn{2}{c}{ Operating Costs (\$/gal ethanol) } \\
\hline Shelled Corn & 0.40 \\
Biomass Feedstock & 0.26 \\
CSL & 0.02 \\
Cellulase & 0.15 \\
Other Raw Materials & 0.12 \\
Waste Disposal & 0.04 \\
Electricity & -0.07 \\
Fixed Costs & 0.23 \\
Denaturant & 0.02 \\
DDG Co-product & 0.00 \\
Starch Utilities & 0.00 \\
Capital Depreciation & 0.30 \\
Total Product Cost per Gallon & 1.46 \\
\multicolumn{1}{c}{ Operating Costs (\$/yr) } \\
\hline Shelled Corn & $\$ 19,800,000$ \\
Feedstock & $\$ 12,700,000$ \\
CSL & $\$ 800,000$ \\
Cellulase & $\$ 7,600,000$ \\
Other Raw Matl. Costs & $\$ 5,700,000$ \\
Denaturant & $\$ 1,100,000$ \\
Waste Disposal & $\$ 1,800,000$ \\
Electricity & $-\$ 3,500,000$ \\
Fixed Costs & $\$ 11,500,000$ \\
DDG Co-product & $\$ 0$ \\
Starch Utilities & $\$ 0$ \\
Capital Depreciation & $\$ 14,700,000$ \\
Total Annual Production Cost & $72,200,000$
\end{tabular}




\title{
Scenario 5a: Combined C6 Fermentation, C5 sugars Separated and Burned Ethanol Production Process Engineering Analysis
}

\author{
Dilute Acid Prehydrolysis with Saccharification and Co-Fermentation
}

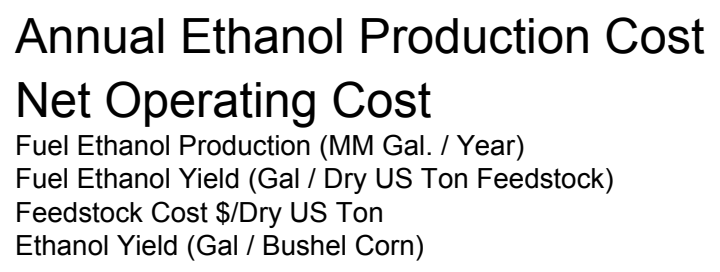

Total Combined Capital Investment

\author{
All Values in $2002 \$$
}

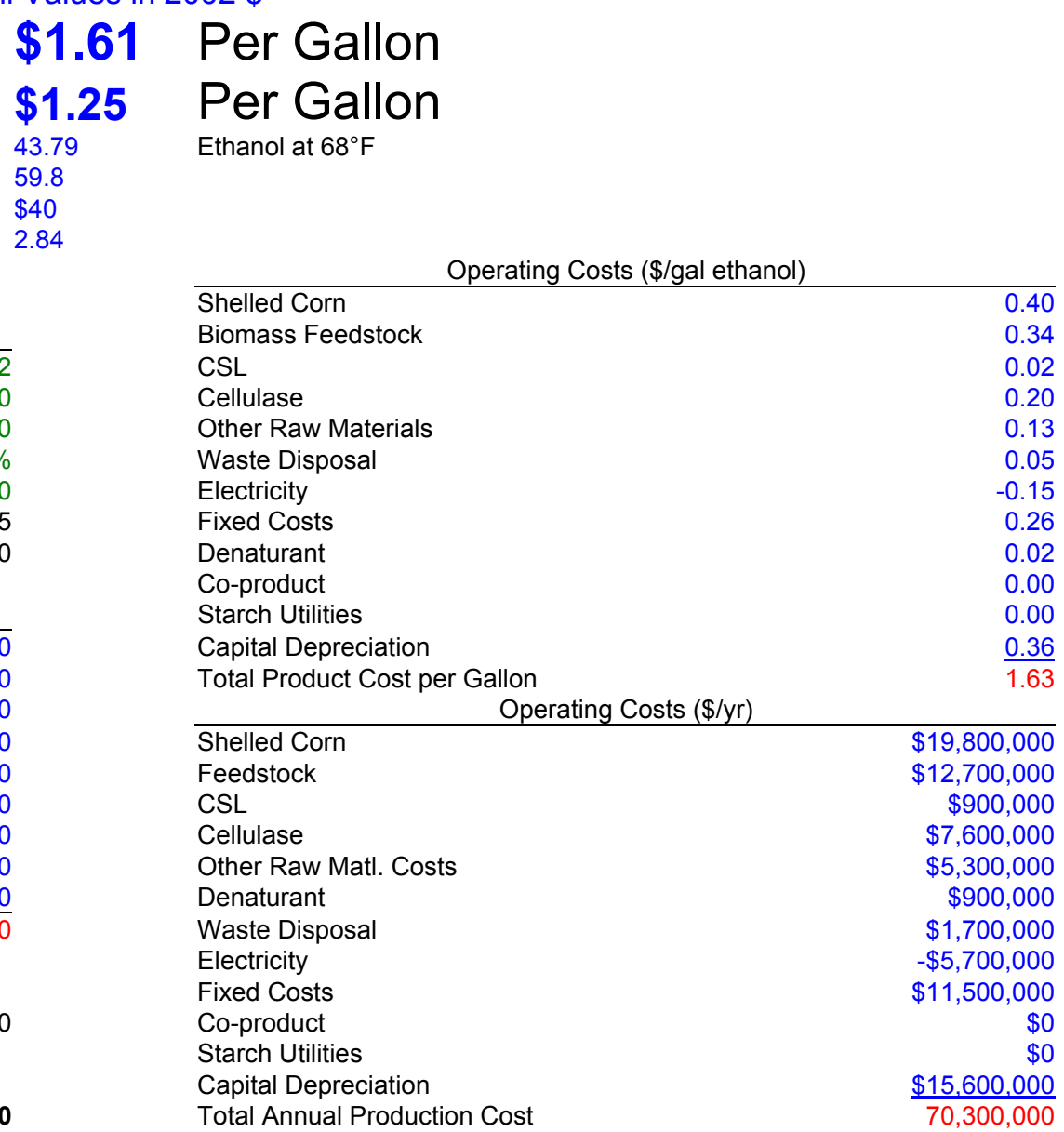




\section{Scenario 5b: Combined C6 Fermentation, C5 sugars Separated and Sold Ethanol Production Process Engineering Analysis}

Dilute Acid Prehydrolysis with Saccharification and Co-Fermentation

\section{All Values in $2002 \$$}

\section{Annual Ethanol Production Cost Net Operating Cost \\ Fuel Ethanol Production (MM Gal. / Year) \\ Fuel Ethanol Yield (Gal / Dry US Ton Feedstock) \\ Feedstock Cost \$/Dry US Ton \\ Ethanol Yield (Gal / Bushel Corn)}

Variables

\begin{tabular}{|c|c|}
\hline \\
\hline Cost Year for Analysis & 2002 \\
\hline Life of Equipment & 10 \\
\hline Days of Operation per Year & 330 \\
\hline$\%$ Denaturant in Final Fuel Ethanol & $5 \%$ \\
\hline Feedstock Cost $\$$ Dry US Ton & $\$ 40$ \\
\hline Feedstock Cost $\$$ / Bushel & $\$ 2.25$ \\
\hline DDGS Price \$/ton & $\$ 80.00$ \\
\hline \multicolumn{2}{|c|}{ Capital Costs } \\
\hline Feed Handling & $\$ 6,700,000$ \\
\hline Pretreatment & $\$ 13,700,000$ \\
\hline Neutralization/Conditioning & $\$ 10,800,000$ \\
\hline Saccharification \& Fermentation & $\$ 18,700,000$ \\
\hline Distillation and Solids Recovery & $\$ 28,300,000$ \\
\hline Wastewater Treatment & $\$ 2,100,000$ \\
\hline Storage & $\$ 2,400,000$ \\
\hline Boiler/Turbogenerator & $\$ 39,200,000$ \\
\hline Utilities & $\$ 7,500,000$ \\
\hline Total Stover Capital Investment & $\$ 129,500,000$ \\
\hline Total Starch Capital Investment & $\$ 4,800,000$ \\
\hline Total Combined Capital Investmen & $\$ 134,300,000$ \\
\hline
\end{tabular}

$\$ 1.37$
$\$ 1.07$
43.61
59.2
$\$ 40$
2.84

Per Gallon

Per Gallon

Ethanol at $68^{\circ} \mathrm{F}$

\begin{tabular}{lr}
\multicolumn{2}{c}{ Operating Costs (\$/gal ethanol) } \\
\hline Shelled Corn & 0.40 \\
Biomass Feedstock & 0.34 \\
CSL & 0.02 \\
Cellulase & 0.20 \\
Other Raw Materials & 0.15 \\
Waste Disposal & 0.05 \\
Electricity & -0.07 \\
Fixed Costs & 0.25 \\
Denaturant & 0.02 \\
Co-product & -0.31 \\
Starch Utilities & 0.00 \\
Capital Depreciation & 0.31 \\
Total Product Cost per Gallon & 1.37 \\
& \\
\hline Shelled Corn & Operating Costs $(\$ / y r)$ \\
Feedstock & $\$ 19,800,000$ \\
CSL & $\$ 12,700,000$ \\
Cellulase & $\$ 800,000$ \\
Other Raw Matl. Costs & $\$ 7,600,000$ \\
Denaturant & $\$ 6,100,000$ \\
Waste Disposal & $\$ 900,000$ \\
Electricity & $\$ 1,800,000$ \\
Fixed Costs & $-\$ 2,500,000$ \\
Co-product & $\$ 10,800,000$ \\
Starch Utilities & $\$ 11,500,000$ \\
Capital Depreciation & $\$ 0$ \\
Total Annual Production Cost & $\$ 13,400,000$ \\
& $59,900,000$
\end{tabular}




\section{Scenario 6: Combined C6 Fermentation, C5s not Fermented Ethanol Production Process Engineering Analysis}

Dilute Acid Prehydrolysis with Saccharification and Co-Fermentation

$$
\text { All Values in } 2002 \$
$$

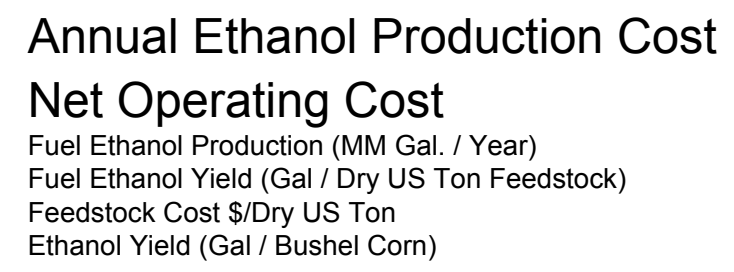

\section{$\$ 1.55$ Per Gallon}

$\$ 1.22$ Per Gallon

\begin{tabular}{|c|c|c|c|}
\hline \multicolumn{2}{|c|}{ Variables } & \multirow{2}{*}{$\begin{array}{l}\text { Shelled Corn } \\
\text { Biomass Feedstock } \\
\text { CSL }\end{array}$} & \multirow{2}{*}{$\begin{array}{l}0.40 \\
0.32 \\
0.03\end{array}$} \\
\hline Cost Year for Analysis & 2002 & & \\
\hline Life of Equipment & 10 & Cellulase & 0.19 \\
\hline Days of Operation per Year & 330 & Other Raw Materials & 0.10 \\
\hline \% Denaturant in Final Fuel Ethanol & $5 \%$ & Waste Disposal & 0.04 \\
\hline Feedstock Cost $\$ /$ Dry US Ton & $\$ 40$ & Electricity & -0.11 \\
\hline Feedstock Cost \$/ Bushel & $\$ 2.25$ & Fixed Costs & 0.25 \\
\hline \multirow[t]{2}{*}{ DDGS Price \$/ton } & $\$ 80.00$ & Denaturant & 0.02 \\
\hline & & DDG Co-product & 0.00 \\
\hline \multicolumn{2}{|c|}{ Capital Costs } & Starch Utilities & 0.00 \\
\hline Feed Handling & $\$ 6,700,000$ & Capital Depreciation & $\underline{0.33}$ \\
\hline Pretreatment & $\$ 13,800,000$ & Total Product Cost per Gallon & 1.56 \\
\hline Neutralization/Conditioning & $\$ 10,900,000$ & \multicolumn{2}{|c|}{ Operating Costs $(\$ / y r)$} \\
\hline Saccharification \& Fermentation & $\$ 19,500,000$ & Shelled Corn & $\$ 19,800,000$ \\
\hline Distillation and Solids Recovery & $\$ 30,800,000$ & Feedstock & $\$ 12,700,000$ \\
\hline Wastewater Treatment & $\$ 2,200,000$ & CSL & $\$ 1,200,000$ \\
\hline Storage & $\$ 2,600,000$ & Cellulase & $\$ 7,600,000$ \\
\hline Boiler/Turbogenerator & $\$ 49,700,000$ & Other Raw Matl. Costs & $\$ 4,200,000$ \\
\hline Utilities & $\$ 6,100,000$ & Denaturant & $\$ 900,000$ \\
\hline \multirow[t]{3}{*}{ Total Stover Capital Investment } & $\$ 142,200,000$ & Waste Disposal & $\$ 1,700,000$ \\
\hline & & Electricity & $-\$ 4,500,000$ \\
\hline & & Fixed Costs & $\$ 11,200,000$ \\
\hline \multirow[t]{3}{*}{ Total Starch Capital Investment } & $\$ 4,800,000$ & DDG Co-product & $\$ 0$ \\
\hline & & Starch Utilities & $\$ 0$ \\
\hline & & Capital Depreciation & $\$ 14,700,000$ \\
\hline Total Combined Capital Investmen & $\$ 147,000,000$ & Total Annual Production Cost & $69,500,000$ \\
\hline
\end{tabular}




\section{Scenario 7: Combined C5 and C6 Fermentation Ethanol Production Process Engineering Analysis}

Dilute Acid Prehydrolysis with Saccharification and Co-Fermentation

$$
\text { All Values in } 2002 \$
$$

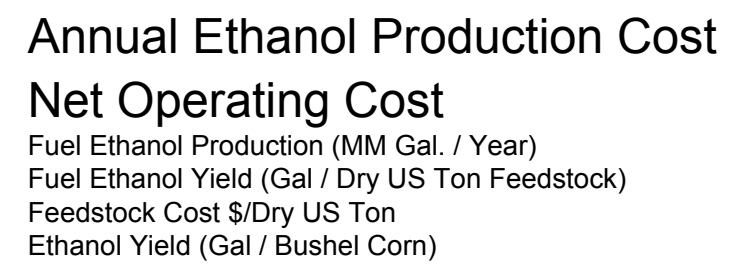

\begin{tabular}{lr} 
& Variables \\
\hline Cost Year for Analysis & 2002 \\
Life of Equipment & 10 \\
Days of Operation per Year & 330 \\
$\%$ Denaturant in Final Fuel Ethanol & $5 \%$ \\
Feedstock Cost \$/Dry US Ton & $\$ 40$ \\
Feedstock Cost \$/ Bushel & $\$ 2.25$ \\
DDGS Price \$/ton & $\$ 80.00$
\end{tabular}

\section{Capital Costs}

Feed Handling
Pretreatment
Neutralization/Conditioning
Saccharification \& Fermentation
Distillation and Solids Recovery
Wastewater Treatment
Storage
Boiler/Turbogenerator
Utilities

Total Stover Capital Investment

Total Starch Capital Investment

Total Combined Capital Investment

\section{$\$ 1.46$ Per Gallon

\$1.16 Per Gallon \\ 49}

76.6

$\$ 40$

2.84

\begin{tabular}{lr}
\multicolumn{2}{c}{ Operating Costs (\$/gal ethanol) } \\
\hline Shelled Corn & 0.40 \\
Biomass Feedstock & 0.26 \\
CSL & 0.02 \\
Cellulase & 0.16 \\
Other Raw Materials & 0.12 \\
Waste Disposal & 0.04 \\
Electricity & -0.10 \\
Fixed Costs & 0.23 \\
Denaturant & 0.02 \\
DDG Co-product & 0.00 \\
Starch Utilities & 0.00 \\
Capital Depreciation & $\underline{0.31}$ \\
Total Product Cost per Gallon & 1.46 \\
& \\
\hline Shelled Corn & $\$ 19,800,000$ \\
Feedstock & $\$ 12,700,000$ \\
CSL & $\$ 1,100,000$ \\
Cellulase & $\$ 7,600,000$ \\
Other Raw Matl. Costs & $\$ 5,900,000$ \\
Denaturant & $\$ 1,100,000$ \\
Waste Disposal & $\$ 1,800,000$ \\
Electricity & $-\$ 4,600,000$ \\
Fixed Costs & $\$ 11,300,000$ \\
DDG Co-product & $\$ 0$ \\
Starch Utilities & $\$ 0$ \\
Capital Depreciation & $\$ 15,100,000$ \\
Total Annual Production Cost & $71,800,000$ \\
&
\end{tabular}




\section{Appendix B:}

MS Excel Summary Sheets for Sensitivity Cases where Solids are Dried and Sold and Evaporation Takes Place ASPEN Models 


\section{Scenario 4: Combined Product Processing Ethanol Production Process Engineering Analysis}

Dilute Acid Prehydrolysis with Saccharification and Co-Fermentation

$$
\text { All Values in } 2002 \$
$$

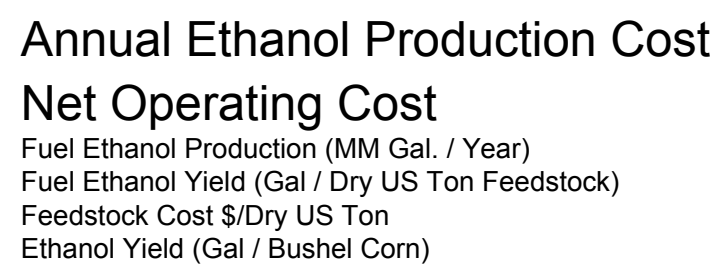

\begin{tabular}{lr}
\multicolumn{2}{c}{ Variables } \\
\hline Cost Year for Analysis & 2002 \\
Life of Equipment & 10 \\
Days of Operation per Year & 330 \\
$\%$ Denaturant in Final Fuel Ethanol & $5 \%$ \\
Feedstock Cost \$/Dry US Ton & $\$ 40$ \\
Feedstock Cost \$/ Bushel & $\$ 2.25$ \\
DDGS Price \$/ton & $\$ 80.00$
\end{tabular}

\begin{tabular}{lr} 
& \\
\hline Feed Handling & $\$ 6,700,000$ \\
Pretreatment & $\$ 13,900,000$ \\
Neutralization/Conditioning & $\$ 10,900,000$ \\
Saccharification \& Fermentation & $\$ 19,200,000$ \\
Distillation and Solids Recovery & $\$ 31,400,000$ \\
Wastewater Treatment & $\$ 6,500,000$ \\
Storage & $\$ 2,600,000$ \\
NG Boiler/ Dryer & $\$ 3,600,000$ \\
Utilities & $\$ 6,600,000$ \\
Total Stover Capital Investment & $\$ 101,400,000$
\end{tabular}

Total Starch Capital Investment

$\$ 9,600,000$

Total Combined Capital Investment

$\$ 111,000,000$

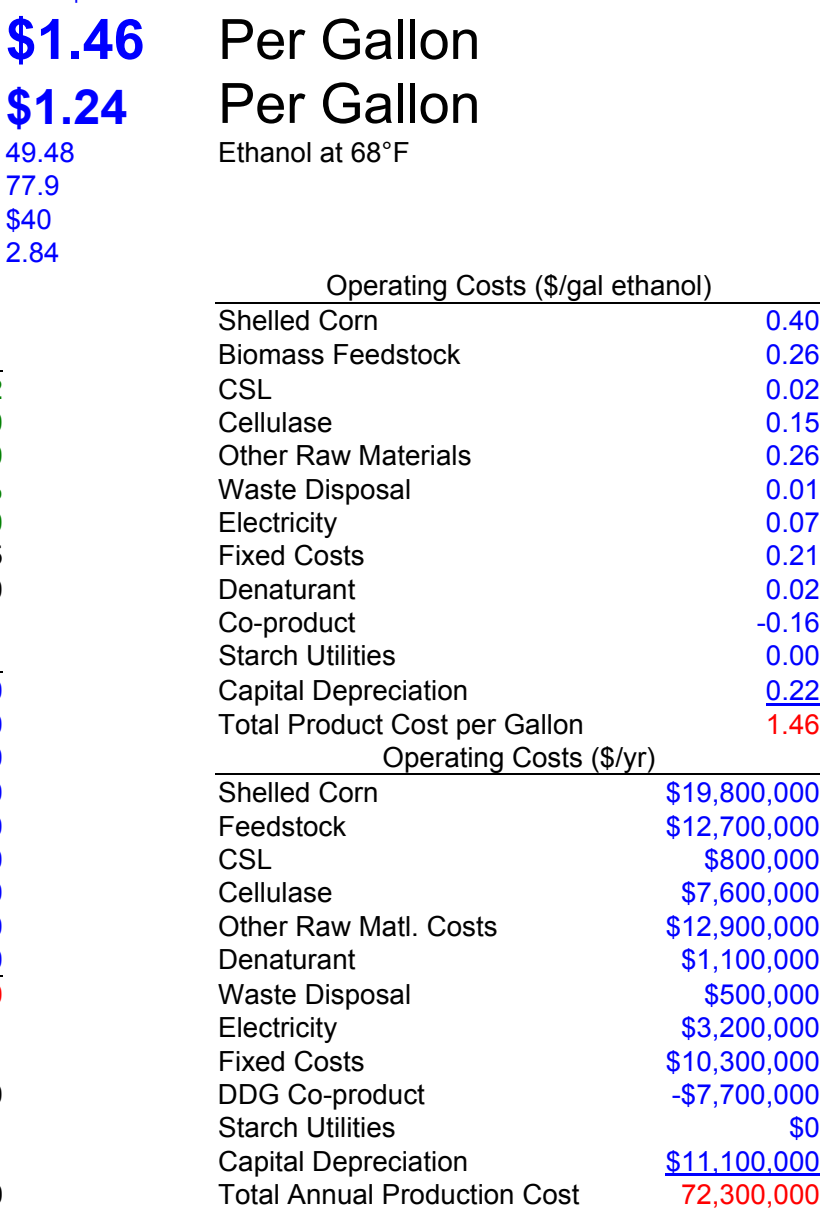




\title{
Scenario5a: Combined C6 Fermentation, C5s Separated, Recombined and Sold with Solids Ethanol Production Process Engineering Analysis
}

\author{
Dilute Acid Prehydrolysis with Saccharification and Co-Fermentation
}

\section{All Values in $2002 \$$}

\section{Annual Ethanol Production Cost}

$\$ 1.68$

Net Operating Cost

Fuel Ethanol Production (MM Gal. / Year)

$\$ 1.42$

Fuel Ethanol Yield (Gal / Dry US Ton Feedstock)

\subsection{9}

Feedstock Cost \$/Dry US Ton

Ethanol Yield (Gal / Bushel Corn)

59.8

$\$ 40$

2.84

\begin{tabular}{|c|c|}
\hline \multicolumn{2}{|c|}{ Variables } \\
\hline Cost Year for Analysis & 2002 \\
\hline Life of Equipment & 10 \\
\hline Days of Operation per Year & 330 \\
\hline$\%$ Denaturant in Final Fuel Ethanol & $5 \%$ \\
\hline Feedstock Cost \$/Dry US Ton & $\$ 40$ \\
\hline Feedstock Cost $\$$ / Bushel & $\$ 2.25$ \\
\hline DDGS Price \$/ton & $\$ 80.00$ \\
\hline \multicolumn{2}{|c|}{ Capital Costs } \\
\hline Feed Handling & $\$ 6,700,000$ \\
\hline Pretreatment & $\$ 13,700,000$ \\
\hline Neutralization/Conditioning & $\$ 10,900,000$ \\
\hline Saccharification \& Fermentation & $\$ 18,800,000$ \\
\hline Distillation and Solids Recovery & $\$ 31,500,000$ \\
\hline Wastewater Treatment & $\$ 13,100,000$ \\
\hline Storage & $\$ 2,400,000$ \\
\hline NG Boiler/Dryer & $\$ 3,900,000$ \\
\hline Utilities & $\$ 6,400,000$ \\
\hline Total Stover Capital Investment & $\$ 107,400,000$ \\
\hline Total Starch Capital Investment & $\$ 4,800,000$ \\
\hline Total Combined Capital Investmer & $\$ 112,200,000$ \\
\hline
\end{tabular}

Per Gallon

Per Gallon

Ethanol at $68^{\circ} \mathrm{F}$

\begin{tabular}{lr}
\multicolumn{2}{c}{ Operating Costs (\$/gal ethanol) } \\
\hline Shelled Corn & 0.40 \\
Biomass Feedstock & 0.34 \\
CSL & 0.02 \\
Cellulase & 0.20 \\
Other Raw Materials & 0.34 \\
Waste Disposal & 0.01 \\
Electricity & 0.10 \\
Fixed Costs & 0.23 \\
Denaturant & 0.02 \\
Co-product & -0.19 \\
Starch Utilities & 0.00 \\
Capital Depreciation & 0.26 \\
Total Product Cost per Gallon & 1.74 \\
& \\
\hline Shelled Corn & $\$ 19$ prating Costs $(\$ / y r)$ \\
Feedstock & $\$ 19,800,000$ \\
CSL & $\$ 12,700,000$ \\
Cellulase & $\$ 900,000$ \\
Other Raw Matl. Costs & $\$ 7,600,000$ \\
Denaturant & $\$ 13,200,000$ \\
Waste Disposal & $\$ 900,000$ \\
Electricity & $\$ 500,000$ \\
Fixed Costs & $\$ 3,800,000$ \\
Co-product & $\$ 10,100,000$ \\
Starch Utilities & $-\$ 7,100,000$ \\
Capital Depreciation & $\$ 0$ \\
Total Annual Production Cost & $\$ 11,200,000$ \\
\hline & $73,600,000$
\end{tabular}




\title{
Scenario5b: Combined C6 Fermentation, C5s Separated and Sold Separately Ethanol Production Process Engineering Analysis
}

Dilute Acid Prehydrolysis with Saccharification and Co-Fermentation

\author{
All Values in $2002 \$$
}

\section{Annual Ethanol Production Cost \\ Net Operating Cost \\ Fuel Ethanol Production (MM Gal. / Year) \\ Fuel Ethanol Yield (Gal / Dry US Ton Feedstock) \\ Feedstock Cost \$/Dry US Ton \\ Ethanol Yield (Gal / Bushel Corn)}

$\$ 1.36$

$\$ 1.13$

\subsection{1}

59.2

$\$ 40$

\begin{tabular}{|c|c|}
\hline \multicolumn{2}{|c|}{ Variables } \\
\hline Cost Year for Analysis & 2002 \\
\hline Life of Equipment & 10 \\
\hline Days of Operation per Year & 330 \\
\hline \% Denaturant in Final Fuel Ethanol & $5 \%$ \\
\hline Feedstock Cost \$/Dry US Ton & $\$ 40$ \\
\hline Feedstock Cost $\$$ / Bushel & $\$ 2.25$ \\
\hline DDGS Price $\$ /$ ton & $\$ 80.00$ \\
\hline \multicolumn{2}{|c|}{ Capital Costs } \\
\hline Feed Handling & $\$ 6,700,000$ \\
\hline Pretreatment & $\$ 13,700,000$ \\
\hline Neutralization/Conditioning & $\$ 10,800,000$ \\
\hline Saccharification \& Fermentation & $\$ 18,700,000$ \\
\hline Distillation and Solids Recovery & $\$ 28,300,000$ \\
\hline Wastewater Treatment & $\$ 3,500,000$ \\
\hline Storage & $\$ 2,400,000$ \\
\hline NG Boiler/ Dryer & $\$ 3,500,000$ \\
\hline Utilities & $\$ 5,700,000$ \\
\hline Total Stover Capital Investment & $\$ 93,300,000$ \\
\hline Total Starch Capital Investment & $\$ 4,800,000$ \\
\hline Total Combined Capital Investment & $\$ 98,100,000$ \\
\hline
\end{tabular}

\begin{tabular}{lr}
\multicolumn{2}{c}{ Operating Costs (\$/gal ethanol) } \\
\hline Shelled Corn & 0.40 \\
Biomass Feedstock & 0.34 \\
CSL & 0.02 \\
Cellulase & 0.20 \\
Other Raw Materials & 0.34 \\
Waste Disposal & 0.01 \\
Electricity & 0.08 \\
Fixed Costs & 0.22 \\
Denaturant & 0.02 \\
Co-product & -0.49 \\
Starch Utilities & 0.00 \\
Capital Depreciation & $\underline{0.22}$ \\
Total Product Cost per Gallon & 1.37 \\
& \\
\hline Shelled Corn & $\$ 19,800,000$ \\
Feedstock & $\$ 12,700,000$ \\
CSL & $\$ 800,000$ \\
Cellulase & $\$ 7,600,000$ \\
Other Raw Matl. Costs & $\$ 13,000,000$ \\
Denaturant & $\$ 900,000$ \\
Waste Disposal & $\$ 500,000$ \\
Electricity & $\$ 2,900,000$ \\
Fixed Costs & $\$ 9,600,000$ \\
DDG Co-product & $-\$ 18,400,000$ \\
Starch Utilities & $\$ 0$ \\
Capital Depreciation & $\$ 9,800,000$ \\
Total Annual Production Cost & $59,200,000$ \\
&
\end{tabular}




\section{Scenario 6: Combined C6 Fermentation, C5s left in Ethanol Production Process Engineering Analysis}

ADDED DRYER AND BIOMASS IS SOLD INSTEAD OF BURNED

Dilute Acid Prehydrolysis with Saccharification and Co-Fermentation

$\begin{array}{lc} & \text { All Values in } 2002 \$ \\ \text { Annual Ethanol Production Cost } & \$ 1.63 \\ \text { Net Operating Cost } & \$ 1.38 \\ \text { Fuel Ethanol Production (MM Gal. / Year) } & 45 \\ \text { Fuel Ethanol Yield (Gal Dry US Ton Feedstock) } & 63.1 \\ \text { Feedstock Cost } \$ \text { IIry US Ton } & \$ 40 \\ \text { Ethanol Yield (Gal / Bushel Corn) } & 2.84\end{array}$

Per Gallon

Per Gallon

Ethanol at $68^{\circ} \mathrm{F}$

Variables

\begin{tabular}{|c|c|c|c|}
\hline \multicolumn{2}{|c|}{ Variables } & \multirow{2}{*}{$\begin{array}{l}\text { Biomass Feedstock } \\
\text { CSL }\end{array}$} & \multirow{2}{*}{$\begin{array}{l}0.32 \\
0.03\end{array}$} \\
\hline Cost Year for Analysis & 2002 & & \\
\hline Life of Equipment & 10 & Cellulase & 0.19 \\
\hline Days of Operation per Year & 330 & Other Raw Materials & 0.31 \\
\hline$\%$ Denaturant in Final Fuel Ethanol & $5 \%$ & Waste Disposal & 0.01 \\
\hline Feedstock Cost $\$ /$ Dry US Ton & $\$ 40$ & Electricity & 0.09 \\
\hline Feedstock Cost $\$$ / Bushel & $\$ 2.25$ & Fixed Costs & 0.22 \\
\hline DDGS Price \$/ton & $\$ 80.00$ & Denaturant & 0.02 \\
\hline & & DDG Co-product & -0.18 \\
\hline \multicolumn{2}{|c|}{ Capital Costs } & Starch Utilities & 0.00 \\
\hline Feed Handling & $\$ 6,700,000$ & Capital Depreciation & $\underline{0.25}$ \\
\hline Pretreatment & $\$ 13,800,000$ & Total Product Cost per Gallon & 1.67 \\
\hline Neutralization/Conditioning & $\$ 10,900,000$ & \multicolumn{2}{|c|}{ Operating Costs $(\$ / y r)$} \\
\hline Saccharification \& Fermentation & $\$ 19,500,000$ & Shelled Corn & $\$ 19,800,000$ \\
\hline Distillation and Solids Recovery & $\$ 30,800,000$ & Feedstock & $\$ 12,700,000$ \\
\hline Wastewater Treatment & $\$ 11,400,000$ & CSL & $\$ 1,200,000$ \\
\hline Storage & $\$ 2,600,000$ & Cellulase & $\$ 7,600,000$ \\
\hline NG Boiler / Dryer & $\$ 3,800,000$ & Other Raw Matl. Costs & $\$ 12,500,000$ \\
\hline Utilities & $\$ 6,200,000$ & Denaturant & $\$ 900,000$ \\
\hline \multirow[t]{3}{*}{ Total Stover Capital Investment } & $\$ 105,700,000$ & Waste Disposal & $\$ 500,000$ \\
\hline & & Electricity & $\$ 3,700,000$ \\
\hline & & Fixed Costs & $\$ 10,000,000$ \\
\hline \multirow[t]{3}{*}{ Total Starch Capital Investment } & $\$ 4,800,000$ & DDG Co-product & $\$ 0$ \\
\hline & & Starch Utilities & $\$ 0$ \\
\hline & & Capital Depreciation & $\$ 11,100,000$ \\
\hline Total Combined Capital Investment & $\$ 110,500,000$ & Total Annual Production Cost & $80,000,000$ \\
\hline
\end{tabular}




\section{Scenario 7: Combined C5 and C6 Fermentation \\ Ethanol Production Process Engineering Analysis \\ ADDED DRYER AND BIOMASS IS SOLD INSTEAD OF BURNED}

Dilute Acid Prehydrolysis with Saccharification and Co-Fermentation

$\begin{array}{lc} & \text { All Values in } 2002 \$ \\ \text { Annual Ethanol Production Cost } & \$ 1.51 \\ \text { Net Operating Cost } & \$ 1.29 \\ \text { Fuel Ethanol Production (MM Gal. / Year) } & 49 \\ \text { Fuel Ethanol Yield (Gal/ Dry US Ton Feedstock) } & 76.6 \\ \text { Feedstock Cost } \$ \text { /Dry US Ton } & \$ 40 \\ \text { Ethanol Yield (Gal / Bushel Corn) } & 2.84\end{array}$

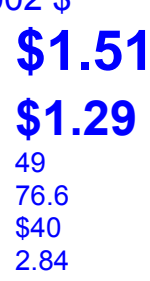

\begin{tabular}{lr} 
& Variables \\
\hline Cost Year for Analysis & 2002 \\
Life of Equipment & 10 \\
Days of Operation per Year & 330 \\
$\%$ Denaturant in Final Fuel Ethanol & $5 \%$ \\
Feedstock Cost \$/Dry US Ton & $\$ 40$ \\
Feedstock Cost \$/ Bushel & $\$ 2.25$ \\
DDGS Price \$/ton & $\$ 80.00$
\end{tabular}

\begin{tabular}{lr}
\multicolumn{2}{c}{ Capital Costs } \\
\hline Feed Handling & $\$ 6,700,000$ \\
Pretreatment & $\$ 13,700,000$ \\
Neutralization/Conditioning & $\$ 11,000,000$ \\
Saccharification \& Fermentation & $\$ 19,500,000$ \\
Distillation and Solids Recovery & $\$ 32,100,000$ \\
Wastewater Treatment & $\$ 7,000,000$ \\
Storage & $\$ 2,700,000$ \\
NG Boiler/Dryer & $\$ 3,800,000$ \\
Utilities & $\$ 6,400,000$ \\
Total Stover Capital Investment & $\$ 102,900,000$
\end{tabular}

Total Starch Capital Investment

$\$ 4,800,000$

Total Combined Capital Investment

$\$ 107,700,000$

\section{Per Gallon}

Per Gallon

Ethanol at $68^{\circ} \mathrm{F}$

\begin{tabular}{lr}
\multicolumn{2}{c}{ Operating Costs (\$/gal ethanol) } \\
\hline Shelled Corn & 0.40 \\
Biomass Feedstock & 0.26 \\
CSL & 0.02 \\
Cellulase & 0.16 \\
Other Raw Materials & 0.29 \\
Waste Disposal & 0.01 \\
Electricity & 0.07 \\
Fixed Costs & 0.20 \\
Denaturant & 0.02 \\
DDG Co-product & -0.15 \\
Starch Utilities & 0.00 \\
Capital Depreciation & 0.22 \\
Total Product Cost per Gallon & 1.51 \\
& \\
\hline Shelled Corn & $\$ 19,800,000$ \\
Feedstock & $\$ 12,700,000$ \\
CSL & $\$ 1,100,000$ \\
Cellulase & $\$ 7,600,000$ \\
Other Raw Matl. Costs & $\$ 13,800,000$ \\
Denaturant & $\$ 1,100,000$ \\
Waste Disposal & $\$ 500,000$ \\
Electricity & $\$ 3,600,000$ \\
Fixed Costs & $\$ 9,900,000$ \\
DDG Co-product & $\$ 0$ \\
Starch Utilities & $\$ 0$ \\
Capital Depreciation & $\$ 10,800,000$ \\
Total Annual Production Cost & $80,900,000$
\end{tabular}




\section{Appendix C:}

MS Excel Summary Sheets for Sensitivity Cases where Solids are dried and sold and the evaporators are Removed from the ASPEN Models 


\section{Scenario 4: Combined Product Processing Ethanol Production Process Engineering Analysis}

dryer added and biomass solids stream sold instead of burned, evaps removed

Dilute Acid Prehydrolysis with Saccharification and Co-Fermentation

All Values in $2002 \$$

\section{Annual Ethanol Production Cost\$1.41 Per Gallon \\ Net Operating Cost\$1.20 Per Gallon}

Fuel Ethanol Production (MM Gal. / Year) $49.50 \quad$ Ethanol at $68^{\circ} \mathrm{F}$

Fuel Ethanol Yield (Gal / Dry US Ton Feedstock) 78.0

Feedstock Cost $\$$ /Dry US Ton $\$ 40$

Ethanol Yield (Gal / Bushel Corn)2.84

\begin{tabular}{|c|c|}
\hline \multicolumn{2}{|c|}{ Variables } \\
\hline Cost Year for Analysis & 2002 \\
\hline Life of Equipment & 10 \\
\hline Days of Operation per Year & 330 \\
\hline$\%$ Denaturant in Final Fuel Ethanol & $5 \%$ \\
\hline Feedstock Cost \$/Dry US Ton & $\$ 40$ \\
\hline Feedstock Cost \$/ Bushel & $\$ 2.25$ \\
\hline DDGS Price \$/ton & $\$ 80.00$ \\
\hline \multicolumn{2}{|l|}{ Capital Costs } \\
\hline Feed Handling & $\$ 6,700,000$ \\
\hline Pretreatment & $\$ 13,600,000$ \\
\hline Neutralization/Conditioning & $\$ 11,000,000$ \\
\hline Saccharification \& Fermentation & $\$ 19,200,000$ \\
\hline Distillation and Solids Recovery & $\$ 23,000,000$ \\
\hline Wastewater Treatment & $\$ 8,000,000$ \\
\hline Storage & $\$ 2,600,000$ \\
\hline NG Boiler/ Dryer & $\$ 3,400,000$ \\
\hline Utilities & $\$ 5,600,000$ \\
\hline Total Stover Capital Investment & $\$ 93,300,000$ \\
\hline Total Starch Capital Investment & $\$ 9,600,000$ \\
\hline
\end{tabular}

\begin{tabular}{lr}
\multicolumn{2}{c}{ Operating Costs (\$/gal ethanol) } \\
\hline Shelled Corn & 0.40 \\
Biomass Feedstock & 0.26 \\
CSL & 0.02 \\
Cellulase & 0.15 \\
Other Raw Materials & 0.24 \\
Waste Disposal & 0.01 \\
Electricity & 0.06 \\
Fixed Costs & 0.20 \\
Denaturant & 0.02 \\
Co-product & -0.16 \\
Starch Utilities & 0.00 \\
Capital Depreciation & $\underline{0.21}$ \\
Total Product Cost per Gallon & 1.41 \\
& \\
\hline Shelled Corn & $\$ 19,800,000$ \\
Feedstock & $\$ 12,700,000$ \\
CSL & $\$ 800,000$ \\
Cellulase & $\$ 7,600,000$ \\
Other Raw Matl. Costs & $\$ 11,600,000$ \\
Denaturant & $\$ 1,100,000$ \\
Waste Disposal & $\$ 500,000$ \\
Electricity & $\$ 3,100,000$ \\
Fixed Costs & $\$ 10,000,000$ \\
DDG Co-product & $-\$ 7,700,000$ \\
Starch Utilities & $\$ 0$ \\
Capital Depreciation & $\$ 10,300,000$ \\
Total Annual Production Cost & $69,800,000$
\end{tabular}




\title{
Scenario 5a: Combined C6 Fermentation, C5s Separated, Recombined and Sold with Solids Ethanol Production Process Engineering Analysis
}

Dilute Acid Prehydrolysis with Saccharification and Co-Fermentation

\author{
All Values in $2002 \$$
}

\section{Annual Ethanol Production Cost\$1.54 Per Gallon}

Net Operating Cost\$1.31 Per Gallon

\author{
Fuel Ethanol Production (MM Gal. / Year)43.81 Ethanol at $68^{\circ} \mathrm{F}$
}

Feedstock Cost $\$ /$ Dry US Ton $\$ 40$

Ethanol Yield (Gal / Bushel Corn)2.84

Variables

\begin{tabular}{lr}
\hline \multicolumn{2}{c}{ Variables } \\
\hline Cost Year for Analysis & 2002 \\
Life of Equipment & 10 \\
Days of Operation per Year & 330 \\
\% Denaturant in Final Fuel Ethanol & $5 \%$ \\
Feedstock Cost \$/Dry US Ton & $\$ 40$ \\
Feedstock Cost \$/ Bushel & $\$ 2.25$ \\
DDGS Price \$/ton & $\$ 80.00$ \\
\multicolumn{1}{c}{ Capital Costs } \\
$\quad$ Feed Handling \\
$\quad$ Pretreatment \\
$\quad$ Neutralization/Conditioning \\
$\quad$ Saccharification \& Fermentation \\
$\quad$ Distillation and Solids Recovery \\
$\quad \$ 13,700,000,000$ \\
$\quad$ Wastewater Treatment & $\$ 21,600,000,000$ \\
$\quad$ Storage & $\$ 14,800,000$ \\
$\quad$ NG Boiler/Dryer & $\$ 2,400,000$ \\
$\quad$ Utilities & $\$ 3,300,000$ \\
Total Stover Capital Investment & $\$ 5,100,000$ \\
$\quad$ & $\$ 97,300,000$ \\
Total Starch Capital Investment & $\$ 4,800,000$
\end{tabular}

Total Combined Capital Investment $\$ 102,100,000$

\begin{tabular}{lr}
\multicolumn{2}{c}{ Operating Costs (\$/gal ethanol) } \\
\hline Shelled Corn & 0.40 \\
Biomass Feedstock & 0.34 \\
CSL & 0.02 \\
Cellulase & 0.20 \\
Other Raw Materials & 0.23 \\
Waste Disposal & 0.01 \\
Electricity & 0.09 \\
Fixed Costs & 0.22 \\
Denaturant & 0.02 \\
Co-product & -0.19 \\
Starch Utilities & 0.00 \\
Capital Depreciation & 0.23 \\
Total Product Cost per Gallon & 1.58 \\
\multicolumn{1}{c}{ Operating Costs (\$/yr) } & \\
\hline Shelled Corn & $\$ 19,800,000$ \\
Feedstock & $\$ 12,700,000$ \\
CSL & $\$ 900,000$ \\
Cellulase & $\$ 7,600,000$ \\
Other Raw Matl. Costs & $\$ 8,900,000$ \\
Denaturant & $\$ 900,000$ \\
Waste Disposal & $\$ 500,000$ \\
Electricity & $\$ 3,400,000$ \\
Fixed Costs & $\$ 9,700,000$ \\
Co-product & $-\$ 7,100,000$ \\
Starch Utilities & $\$ 0$ \\
Capital Depreciation & $\$ 10,200,000$ \\
Total Annual Production Cost & $67,500,000$ \\
&
\end{tabular}




\section{Scenario 5b: Combined C6 Fermentation, C5s Separated and Sold Separately Ethanol Production Process Engineering Analysis}

dryer added and biomass solids stream sold instead of burned

Dilute Acid Prehydrolysis with Saccharification and Co-Fermentation

All Values in $2002 \$$

Annual Ethanol Production Cost\$1.33 Per Gallon

Net Operating Cost\$1.11 Per Gallon

Fuel Ethanol Production (MM Gal. / Year) 43.62

Fuel Ethanol Yield (Gal / Dry US Ton Feedstock) 59.2

Feedstock Cost $\$$ /Dry US Ton $\$ 40$

Ethanol Yield (Gal / Bushel Corn)2.84

\begin{tabular}{lr}
\multicolumn{2}{c}{ Variables } \\
\hline Cost Year for Analysis & 2002 \\
Life of Equipment & 10 \\
Days of Operation per Year & 330 \\
\% Denaturant in Final Fuel Ethanol & $5 \%$ \\
Feedstock Cost \$/Dry US Ton & $\$ 40$ \\
Feedstock Cost \$/ Bushel & $\$ 2.25$ \\
DDGS Price \$/ton & $\$ 80.00$ \\
\multicolumn{1}{c}{ Capital Costs } \\
\hline Feed Handling \\
$\quad$ Pretreatment \\
$\quad$ Neutralization/Conditioning \\
$\quad$ Saccharification \& Fermentation \\
$\quad$ Distillation and Solids Recovery & $\$ 13,70,000,000$ \\
$\quad$ Wastewater Treatment & $\$ 4,000,000$ \\
$\quad$ Storage & $\$ 2,400,000$ \\
$\quad$ NG Boiler/ Dryer & $\$ 6,200,000$ \\
$\quad$ Utilities & $\$ 4,800,000$ \\
Total Stover Capital Investment & $\$ 89,000,000$ \\
\multicolumn{2}{l}{} \\
Total Starch Capital Investment & $\$ 4,800,000$ \\
$\quad$ & \\
Total Combined Capital Investment $\$ 93,800,000$
\end{tabular}

\begin{tabular}{lr}
\multicolumn{2}{c}{ Operating Costs (\$/gal ethanol) } \\
\hline Shelled Corn & 0.40 \\
Biomass Feedstock & 0.34 \\
CSL & 0.02 \\
Cellulase & 0.20 \\
Other Raw Materials & 0.29 \\
Waste Disposal & 0.01 \\
Electricity & 0.10 \\
Fixed Costs & 0.22 \\
Denaturant & 0.02 \\
Co-product & -0.49 \\
Starch Utilities & 0.00 \\
Capital Depreciation & $\underline{0.22}$ \\
Total Product Cost per Gallon & 1.33 \\
& \\
\hline Shelled Corn & $\$ 19,800,000$ \\
Feedstock & $\$ 12,700,000$ \\
CSL & $\$ 800,000$ \\
Cellulase & $\$ 7,600,000$ \\
Other Raw Matl. Costs & $\$ 11,400,000$ \\
Denaturant & $\$ 900,000$ \\
Waste Disposal & $\$ 500,000$ \\
Electricity & $\$ 3,700,000$ \\
Fixed Costs & $\$ 9,500,000$ \\
DDG Co-product & $-\$ 18,400,000$ \\
Starch Utilities & $\$ 0$ \\
Capital Depreciation & $\$ 9,400,000$ \\
Total Annual Production Cost & $57,900,000$ \\
&
\end{tabular}




\section{Scenario 6: Combined C6 Fermentation Only Ethanol Production Process Engineering Analysis}

ADDED DRYER AND BIOMASS IS SOLD INSTEAD OF BURNED

Dilute Acid Prehydrolysis with Saccharification and Co-Fermentation

All Values in $2002 \$$

Annual Ethanol Production Cost\$1.53 Per Gallon

Net Operating Cost\$1.31 Per Gallon

Fuel Ethanol Production (MM Gal. / Year) 45

Fuel Ethanol Yield (Gal / Dry US Ton Feedstock)63.2

Feedstock Cost $\$$ /Dry US Ton $\$ 40$

Ethanol Yield (Gal / Bushel Corn)2.84

Variables

\begin{tabular}{|c|c|}
\hline \\
\hline Cost Year for Analysis & 2002 \\
\hline Life of Equipment & 10 \\
\hline Days of Operation per Year & 330 \\
\hline$\%$ Denaturant in Final Fuel Ethanol & $5 \%$ \\
\hline Feedstock Cost \$/Dry US Ton & $\$ 40$ \\
\hline Feedstock Cost \$/ Bushel & $\$ 2.25$ \\
\hline DDGS Price \$/ton & $\$ 80.00$ \\
\hline \multicolumn{2}{|l|}{ Capital Costs } \\
\hline Feed Handling & $\$ 6,700,000$ \\
\hline Pretreatment & $\$ 13,700,000$ \\
\hline Neutralization/Conditioning & $\$ 11,000,000$ \\
\hline Saccharification \& Fermentation & $\$ 19,500,000$ \\
\hline Distillation and Solids Recovery & $\$ 22,300,000$ \\
\hline Wastewater Treatment & $\$ 12,900,000$ \\
\hline Storage & $\$ 2,600,000$ \\
\hline NG Boiler / Dryer & $\$ 3,400,000$ \\
\hline Utilities & $\$ 5,200,000$ \\
\hline Total Stover Capital Investment & $\$ 97,200,000$ \\
\hline
\end{tabular}

Total Starch Capital Investment $\quad \$ 4,800,000$

Total Combined Capital Investment $\$ 102,000,000$

\begin{tabular}{lr}
\multicolumn{2}{c}{ Operating Costs (\$/gal ethanol) } \\
\hline Shelled Corn & 0.40 \\
Biomass Feedstock & 0.32 \\
CSL & 0.03 \\
Cellulase & 0.19 \\
Other Raw Materials & 0.24 \\
Waste Disposal & 0.01 \\
Electricity & 0.08 \\
Fixed Costs & 0.22 \\
Denaturant & 0.02 \\
DDG Co-product & -0.18 \\
Starch Utilities & 0.00 \\
Capital Depreciation & $\underline{0.23}$ \\
Total Product Cost per Gallon $\quad 1.56$ \\
\multicolumn{1}{c}{ Operating Costs $(\$ / y r)$} \\
\hline Shelled Corn & $\$ 19,800,000$ \\
Feedstock & $\$ 12,700,000$ \\
CSL & $\$ 1,200,000$ \\
Cellulase & $\$ 7,600,000$ \\
Other Raw Matl. Costs & $\$ 9,900,000$ \\
Denaturant & $\$ 900,000$ \\
Waste Disposal & $\$ 500,000$ \\
Electricity & $\$ 3,300,000$ \\
Fixed Costs & $\$ 9,700,000$ \\
DDG Co-product & $-\$ 7,000,000$ \\
Starch Utilities & $\$ 0$ \\
Capital Depreciation & $\$ 10,200,000$ \\
Total Annual Production Cost & $68,800,000$
\end{tabular}




\section{Scenario 7: Combined C5 and C6 Fermentation Ethanol Production Process Engineering Analysis ADDED DRYER AND BIOMASS IS SOLD INSTEAD OF BURNED REMOVED EVAPORATORS}

Dilute Acid Prehydrolysis with Saccharification and Co-Fermentation

$$
\text { All Values in } 2002 \text { \$ }
$$

\section{Annual Ethanol Production Cost\$1.42 Per Gallon \\ Net Operating Cost\$1.22 Per Gallon}

Fuel Ethanol Production (MM Gal. / Year)49 Fuel Ethanol Yield (Gal / Dry US Ton Feedstock) 76.6
Feedstock Cost $\$ /$ Dry US Ton $\$ 40$

\begin{tabular}{lr}
\multicolumn{2}{c}{ Variables } \\
\hline Cost Year for Analysis & 2002 \\
Life of Equipment & 10 \\
Days of Operation per Year & 330 \\
\% Denaturant in Final Fuel Ethanol & $5 \%$ \\
Feedstock Cost \$/Dry US Ton & $\$ 40$ \\
Feedstock Cost \$/ Bushel & $\$ 2.25$ \\
DDGS Price \$/ton & $\$ 80.00$ \\
\multicolumn{1}{c}{ Capital Costs } & \\
\hline$\quad$ Feed Handling & $\$ 6,700,000$ \\
$\quad$ Pretreatment & $\$ 13,700,000$ \\
$\quad$ Neutralization/Conditioning & $\$ 11,000,000$ \\
$\quad$ Saccharification \& Fermentation & $\$ 19,500,000$ \\
$\quad$ Distillation and Solids Recovery & $\$ 23,400,000$ \\
$\quad$ Wastewater Treatment & $\$ 8,700,000$ \\
$\quad$ Storage & $\$ 2,700,000$ \\
NG Boiler/Dryer & $\$ 3,400,000$ \\
$\quad$ Utilities & $\$ 5,300,000$ \\
Total Stover Capital Investment & $\$ 94,400,000$ \\
$\quad$ & \\
Total Starch Capital Investment & $\$ 4,800,000$ \\
$\quad$ & \\
Total Combined Capital Investment $\$ 99,200,000$
\end{tabular}

\begin{tabular}{lr}
\multicolumn{2}{c}{ Operating Costs (\$/gal ethanol) } \\
\hline Shelled Corn & 0.40 \\
Biomass Feedstock & 0.26 \\
CSL & 0.02 \\
Cellulase & 0.16 \\
Other Raw Materials & 0.24 \\
Waste Disposal & 0.01 \\
Electricity & 0.06 \\
Fixed Costs & 0.20 \\
Denaturant & 0.02 \\
DDG Co-product & -0.15 \\
Starch Utilities & 0.00 \\
Capital Depreciation & $\underline{0.20}$ \\
Total Product Cost per Gallon & 1.43 \\
\multicolumn{1}{c}{ Operating Costs $(\$ / y r)$} & \\
\hline Shelled Corn & $\$ 19,800,000$ \\
Feedstock & $\$ 12,700,000$ \\
CSL & $\$ 1,100,000$ \\
Cellulase & $\$ 7,600,000$ \\
Other Raw Matl. Costs & $\$ 11,400,000$ \\
Denaturant & $\$ 1,100,000$ \\
Waste Disposal & $\$ 500,000$ \\
Electricity & $\$ 3,100,000$ \\
Fixed Costs & $\$ 9,600,000$ \\
DDG Co-product & $\$ 7,100,000$ \\
Starch Utilities & $\$ 0$ \\
Capital Depreciation & $\$ 9,900,000$ \\
Total Annual Production Cost & $69,700,000$ \\
&
\end{tabular}




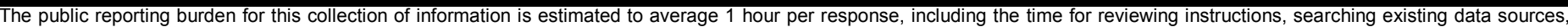

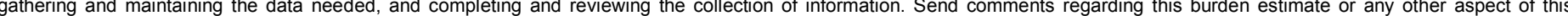

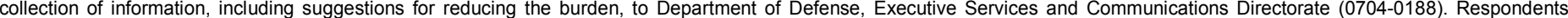

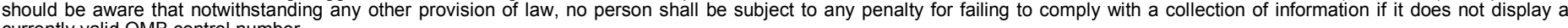
currently valid OMB control number.

PLEASE DO NOT RETURN YOUR FORM TO THE ABOVE ORGANIZATION.

\section{REPORT DATE (DD-MM-YYYY) January 2005 \\ 2. REPORT TYPE \\ Technical Report}

4. TITLE AND SUBTITLE

Feasibility Study for Co-Locating and Integrating Ethanol Production Plants from Corn Starch and Lignocellulosic Feedstocks (Revised)
3. DATES COVERED (From - To)

5a. CONTRACT NUMBER

DE-AC36-99-GO10337

5c. PROGRAM ELEMENT NUMBER

6. AUTHOR(S)

Robert Wallace, Kelly Ibsen, Andrew McAloon, and Winnie Yee

5d. PROJECT NUMBER

NREL/TP-510-37092

5e. TASK NUMBER

BB05.6140

5f. WORK UNIT NUMBER

7. PERFORMING ORGANIZATION NAME(S) AND ADDRESS(ES)

National Renewable Energy Laboratory

1617 Cole Blvd.

Golden, CO 80401-3393

and

Eastern Regional Research Center

Agricultural Research Service

600 E. Mermaid Lane

Wyndmoor, PA 19038-8598

9. SPONSORING/MONITORING AGENCY NAME(S) AND ADDRESS(ES)

10. SPONSOR/MONITOR'S ACRONYM(S) NREL

11. SPONSORING/MONITORING AGENCY REPORT NUMBER

12. DISTRIBUTION AVAILABILITY STATEMENT

National Technical Information Service

U.S. Department of Commerce

5285 Port Royal Road

Springfield, VA 22161

13. SUPPLEMENTARY NOTES

\section{ABSTRACT (Maximum 200 Words)}

Analysis of the feasibility of co-locating corn-grain-to-ethanol and lignocellulosic ethanol plants and potential savings from combining utilities, ethanol purification, product processing, and fermentation. Although none of the scenarios identified could produce ethanol at lower cost than a straight grain ethanol plant, several were lower cost than a straight cellulosic ethanol plant.

\section{SUBJECT TERMS}

biofuels; ethanol; fuels; chemicals; co-location; sugars; biomass; bioproducts; corn; lignocellulosic ethanol

\begin{tabular}{|c|c|c|c|c|}
\hline \multicolumn{3}{|c|}{ 16. SECURITY CLASSIFICATION OF: } & \multirow{2}{*}{$\begin{array}{l}\text { 17. LIMITATION } \\
\text { OF ABSTRACT } \\
\text { UL }\end{array}$} & \multirow{2}{*}{$\begin{array}{ll}\text { 18. } & \text { NUMBER } \\
\text { OF PAGES }\end{array}$} \\
\hline $\begin{array}{l}\text { a. REPORT } \\
\text { Unclassified }\end{array}$ & $\begin{array}{l}\text { b. ABSTRACT } \\
\text { Unclassified }\end{array}$ & $\begin{array}{l}\text { c. THIS PAGE } \\
\text { Unclassified }\end{array}$ & & \\
\hline
\end{tabular}

19a. NAME OF RESPONSIBLE PERSON

19b. TELEPONE NUMBER (Include area code) 